\title{
Azerbaycan-Ermenistan Çatışması Haber Metinlerinin Eleştirel Söylem Çözümlemesi
}

- Ömer Faruk Zararsız Arș. Gör. Ankara Hacı Bayram Veli Üniversitesi omer.zararsiz@hbv.edu.tr ORCID ID: 0000-0002-04857576

\section{- Ahmet Selman}

\section{Seyhan}

Öğr. Gör. Dr. Ankara Hacı Bayram Veli Üniversitesi a.seyhan@hbv.edu.tr ORCID ID: 0000-0003-47640278

\section{ÖZET}

Eleştirel yaklaşım, liberal yaklaşımın savunduğu haber metinlerinin olayları aktarırken ayna vazifesi görmesi ve tarafsız aktarımda bulunması görüşüne karşı basın kuruluşlarının zaman zaman devletin ideolojik aygitı işlevini üstlenerek iktidarın sahip olmuş olduğu ideolojiyi yeniden ürettiğini iddia etmektedir. Basın kuruluşlarının ideolojiyi yeniden üretiminde pek çok farklı unsur devreye girmektedir. Ekonomik veya siyasi bağlllıkların yanında kültür, kimlik veya dini sebepler de ideolojik yakınlı̆̆ın sebepleri olabilmektedir. Bu sebepler haber metinlerine yansiyarak ideolojinin söylemi șekillendirmesini să̆layabilmektedir. Bu kapsamda Türkiye-Azerbaycan arasındaki ilişkinin tarihsel, kültürel, dini veya dil gibi ortak yönleri ışı̆̆ında ve TürkiyeErmenistan arasindaki ilișkide de tarihsel ardalan devletin ideolojisini belirlemekte önemli rol üstlenmektedir. Bu bağlamda Azerbaycan-Ermenistan arasinda Karabăg bölgesinde süren çatışmaların farklı ideolojiye sahip olan Cumhuriyet, Türkgün ve Sabah gazetelerindeki haber söylemine nasil yansıdiğ van Dijk'ın eleştirel söylem çözümlemesi modeli uygulanarak incelenmiştir. Çalışma sonunda, Türkiye'nin Karabă̆ sorunununda, Azerbaycan ve Ermenistan konusunda sahip olduğu ideolojik kabulün üç gazete tarafindan nasıl yansitıldiğg tespit edilmiștir. Elde edilen sonuçlarda her üç gazetenin söylemlerinin etnik temelde birleștiği ancak ideoloji, din ve kültürel olarak farklılaştı̆̆ sonucuna ulaşılmıştır. Özellikle Sabah ve Türkgün gazetelerinin Cumhuriyet gazetesine göre daha fazla milliyetçi-muhafazakar ve Azerbaycan yanlısı bir söylem geliştridiği söz konusu farklılıklar arasındadır.

Anahtar Sözcükler: İdeoloji, Söylem, Teun van Dijk, Eleştirel Söylem Çözümlemesi, Haber Çözümlemesi 


\section{Critical Discourse Analysis of News Texts of the Azerbaijan-Armenia Conflict}

- Ömer Faruk Zararsiz Res. Ass. Ankara Haci Bayram Veli University omer.zararsiz@hbv.edu.tr ORCID ID: 0000-0002-04857576

- Ahmet Selman Seyhan Lecturer Dr. Ankara Haci Bayram Veli University a.seyhan@hbv.edu.tr ORCID ID: 0000-0003-47640278

\begin{abstract}
The critical approach claims that press organizations from time to time reproduce the ideology that power has, assuming the function of the ideological apparatus of the state, against the view that news texts advocated by the liberal approach act as mirrors when conveying events and transmit impartially. Many different elements come into play in the reproduction of ideology by press organizations. In addition to economic or political affiliations, culture, identity, or religious motivations can also be reasons for ideological intimacy. These reasons can be reflected in the news texts and enable ideology to shape the discourse. Therefore, the historical background plays an important role in determining the ideology of the state in the light of the historical, cultural, religious or linguistic aspects of the relationship between Turkey and Azerbaijan, and in the relationship between Turkey and Armenia. Thus, how the conflict between Azerbaijan and Armenia in the Karabakh region reflected on Cumhuriyet, Turkgun and Sabah newspapers within the framework of these effects of ideology was examined by applying van Dijk's discourse analysis model. Eventually, it was determined how the ideological acceptance of Turkey in the Karabakh conflict, Azerbaijan and Armenia, was reflected by three newspapers. Finally, it was concluded that discourses of all three newspapers were ethnically unified but differed in ideology, religion and culture. Among the differences in question is that the newspapers Sabah and Turkgun, in particular, developed a more nationalistconservative and Pro-Azerbaijani discourse than Cumhuriyet newspaper.
\end{abstract}

Keywords: Ideology, Discourse, Teun van Dijk, Critical Discourse Analysis, News Analysis 


\section{GIIRIŞ̧}

Türkiye ve Azerbaycan dil, kültür, din, etnik kökeni paylaşmaları ve Gürcistan, Ermenistan, İran ve Rusya ile ortak sınırları olması bakımından önemli ilişkileri olan iki devlettir. Türkiye ve Azerbaycan arasındaki söz konusu bağlar aynı zamanda iki ülke arasındaki sosyal, siyasi ve politik alanda belirleyici olabilmektedir. Tek millet, iki devlet retoriğine de yansıyan ortaklık iki ülke arasındaki özel bağları temsil etmektedir. Söz konusu bağlar iki devlet arasındaki ilişkileri gerek ulusal gerekse uluslararası anlamda, boyut, içerik, söylem ve ideoloji gibi alanlarda çoğunlukla doğrudan, kısmen de dolaylı etkilemektedir. İki ülkenin genellikle ortak olarak hareket ettiği diğer bir nokta ise Ermenistan'a karşı olan tutum ve Ermenistan'ın Karabağ bölgesini işgalidir. Türkiye'nin Ermeniler ile olan sorunları Osmanlı İmparatorluğu dönemine, devletler nezdindeki sorunlar ise Ermenistan'ın devlet olarak kurulduğu tarihin hemen sonrasına dayanmaktadır. Azerbaycan'in Ermenistanla olan sorunları ise Sovyet Sosyalist Cumhuriyetler Birliği'nin (SSCB) dağılması ardından Ermenistan'ın Azerbaycan topraklarında ve Karabağ bölgesindeki hak iddialarının yanı sıra işgaline de dayanmaktadır.

$\mathrm{Bu}$ çalışmada gazete haberlerinin yanlılığı, ideolojinin söylemi şekillendirmesi üzerinde durulmaktadır. Haberlerde yanlılık, söyleme yansıyan ideoloji ve iktidar ilişkilerinin ortaya koyulabilmesi açısından Ermenistanla Azerbaycan arasında yaşanan çatışmaların eleştirel sol anlayışa sahip Cumhuriyet gazetesi, liberal ana akım anlayışa sahip Sabah gazetesi ve milliyetçi muhafazakar anlayışa sahip Türkgün gazetesinde nasıl ele alındığı van Dijk'ın eleştirel söylem analizi yöntemiyle çözümlemiştir. Böylece Azerbaycan ve Ermenistan arasındaki çatışmaların geniş ideolojik bir yelpazede gazete söylemlerine nasıl yansıdığı tespit edilebilecek olup, söylemlerdeki farklılıkların veya varsa benzerliklerin daha doğru tespit edlmesi sağlanacaktır. Çalışmada, çatışmaların başlamasından Rusya Federasyonu'nun arabuluculuğuyla ateşkes ilan edilmesini sağladığı sürece kadar olan 27.09.2020 - 11.10.2020 tarihleri arasındaki haberlerin üç gazetenin birinci sayfalarındaki yansımaları incelenmiştir. Çalışmaların bu tarihlerle sınırlandırılmasında savaş ve barış gibi iki zıt durumun söyleme nasıl yansıdığının ve ideoloji başta olmak üzere diğer etkenlerin bu söylemi nasıl oluşturduğunun tespit edilebilecek olması etkili olmuştur. Haberlere konu olan olay, Ermenistan'ın Azerbaycana saldırması, bu saldırı sonrasında Azerbaycan'ın Karabağ bölgesini yeniden topraklarına katmak üzere Ermenistan'a karşılık vermesi ve Karabağ’’n bir kısmını tekrar ele geçirmesini içermektedir. Üç gazetenin ilk sayfa haberlerinde ilgili tarihlerde yaşanan bu gelişmelerin nasıl ele alındığı, devletin 
ideolojisinin ve gazetelerin ideolojilerinin bu söylemelere nasıl yansıdığının tespit edilmesi amaçlanmaktadır.

Çalışmada öncelikle Türkiye-Azerbaycan ilişkileri tanımlanmış, ardından TürkiyeErmenistan ilişkilerinin özeti verilmiştir. Böylece tarihi, kültürel ve ideolojik altyap1 oluşturulmuştur. Daha sonra çalışmanın konusunu oluşturan Karabağ bölgesindeki çatışmaların kökenleri Türkiye, Azerbaycan ve Ermenistan açısından ele alınarak özetlenmiştir. Bu tanımlamalardan sonra haberi tanımlayan ve açıklayan ana akım liberal yaklaşım ile eleştirel yaklaşım arasındaki farklar, ideolojinin, söylem ve haber metinlerine yansıması çerçevesinde tartışılmıştır. Kuram ve kavram olarak gerekli tanımlamaların ardından çalışmanın yöntem olarak temel aldığı van Dijk'ın eleştirel söylem çözümlemesi açıklanarak ilgili haberler bu modeldeki unsurlara göre çözümlenmiştir. Çalışmada olayların nasıl ele alındığı, haberlerin oluşturulmasında kullanılan kaynaklar ve ideolojinin haberlere yansımaları incelenmiştir. Uluslararası bir sorunda ideoloji ve örtük anlamın gazetelere yansımasını ortaya çıkarması bakımından önemli görülen bu çalışmanın sonuncunda üç gazetenin söyleminde ağırlıklı olarak ideolojinin, kısmi olarak dini, milli ve kültürel yansımanın olduğu sonucuna ulaşılmıştır.

\section{TÜRKIYE, AZERBAYCAN, ERMENISTAN İLIŞKISİ}

Azerbaycan ve Ermenistan arasındaki çatışmaların Türkiye'de yayınlanan gazete haberlerinin metinlerinde söyleme nasıl yansıdığının incelenebilmesi için bu iki ülkenin Türkiye ile olan tarihi, sosyolojik ve siyasi ilişkisinin açıklanması gerekmektedir. Bu açıklamalar ışı̆̆ında habere yansıyan söylem daha doğru analiz edilebilecek ve anlaşılabilecektir.

\subsection{Türkiye-Azerbaycan İlişkileri}

Türkiye ve Azerbaycan arasındaki siyasî ilişkiler 1918 yılında Azerbaycan Demokratik Cumhuriyeti'nin kurulmasıyla başlamıştır. Sovyet Sosyalist Cumhuriyetler Birliğinin dağılmasının ardından Azerbaycan'ın 1991 yılında bağımsızlığını ilan etmesiyle Türkiye ile arasındaki ilişki hem diplomatik hem siyasî hem de toplumsal açıdan daha ileri boyutlara taşınmıştır. Türkiye hem Azerbaycan'ı ilk tanıyan hem de ilk büyükelçi atayan ülke olmuştur. Bunun yanı sıra Dağlık Karabağ Bölgesi nedeniyle Ermenistan ile yaşadığı sorunlarda da Türkiye'nin hem Ermenistan ile sınırlarını kapatması hem de Azerbaycan'1 desteklemesi 
Azerbaycan nezdinde Türkiye'nin önemini pekiştiren unsurlar olmuştur (Ekşi, 2009, s. 98-99). Özellikle Ebülfez Elçibey Dönemiyle birlikte Azerbaycan ve Türkiye arasındaki ilişkiler milliyetçilik ideolojisi çerçevesinde şekillenmiş ve Elçibey’in Türk milliyetçiliğini öne çıkaran politikalarıyla iki ülke arasındaki ilişkiler daha da sıkılaşmıştır (Aslanlı \& Hesenov, 2005, s. 26).

Elçibey'in ardından iktidara gelen Haydar Aliyev döneminde Türkiye ile olan ilişkiler daha da gelişmiştir. SSCB'nin etkilerinden kurtularak tam bağımsızlık çalışmalarıyla yüzünü Türkiye ve Batı'ya dönen Azerbaycan'da, Türkiye ve Azerbaycan ilişkilerinde dostluk ve kardeşlik temalarının öne çıktığını ifade etmek mümkündür (Dikkaya, 2009). Dostluk ve kardeşlik temaları iki "devlet” arasındaki ilişkilerde belirleyici olduğu kadar iki "millet" açısından da en az aynı oranda karşılık bulmaktadır. Haydar Aliyev'in 1994 tarihinde TBMM'de yaptığı ve iki ülkeyi "bir millet, iki devlet” (Şıhaliyev, 2004, s. 160) olarak tanımlaması, ilgili tanımı bir slogana dönüştürmüş ve iki ülke arasındaki ilişkilerde de belirleyici söylem olmuştur. Haydar Aliyev'in ardından Cumhurbaşkanlığg görevine oğlu İlham Aliyev seçilerek bugün görevini sürdürmektedir. İlham Aliyev döneminde Azerbaycan-Türkiye ilişkilerindeki yakınlık devam etmiştir. İlham Aliyev döneminde artan ilişkiler daha çok ekonomi ve enerji yönünde olsa da kültürel ve dini anlamdaki ortak payda ise güçlenerek devam etmektedir. Aliyev'in Cumhurbaşkanlığına seçilmesinin ardından sarf ettiği "Dünyada Türkiye ve Azerbaycan arasındaki sıkı ilişki olan ikinci bir birliktelik bilmiyorum.” (Eren, 2012) ve Türkiye Cumhurbaşkanı Recep Tayyip Erdoğan'ın da “Türkiye ile Azerbaycan kardeş iki millet, iki dost ülkedir” (Eren, 2012) sözleri iki ülke arasındaki ilişkinin boyutlarını ortaya koyması açısından önemlidir.

\subsection{Türkiye-Ermenistan İlişkileri}

Türkiye ile Ermenistan ilişkileri Osmanlı Devleti dönemine dayanmaktadır. Osmanlı Devletinde Millet-i Sadıka olarak adlandırılan Ermeniler, Fransız İhtilali sonrasında başlayan milliyetçilik akımlarından en son etkilenen milletlerden bir tanesini oluşturmaktadır. İsyan hareketlerinin başlamasının ardından Osmanlı Devleti isyanların devamını ve büyümesini engellemek amaciyla tehcir uygulamasına giderek, Ermenilerin yerlerini değiştirmiştir (Arslanl1, 2015, s. 28). 
Türkiye, Ermenistan’ı resmî ve koşulsuz olarak 1991 yılında devlet olarak tanımıştır. Bunun yanı sıra Ermenistan'a yapılacak olan her türlü yardım için hava sahasının kullanılmasına da izin vermiştir. Ayrıca Karadeniz’e sınırı olmadığı halde Karadeniz Ekonomik İşbirliği Örgütü'ne üye olmasını sağlayarak uluslararası alanda tanınmasına yardımcı olmuştur (Demir, 2005, s. 119). Ancak 1992 yılında Karabağ bölgesindeki Hocalı Katliamı sonrasında söz konusu ilişkiler koparak sınırların Türkiye tarafından kapatılmasına ve Türkiye'nin Ermenistan'1 karadan ve havadan ablukaya almasına neden olmuştur.

Cumhuriyet Dönemi Türkiye-Ermenistan ilişkilerinde belirleyici etkenler arasında; SSCB'nin dağılması sonrası Kafkasya ve Türki Cumhuriyetler üzerinde Türkiye'nin etkili olmaya başlaması, Ermenistan'ın Türkiye'nin söz konusu etkisini kırmak için Rusya, İran ve Yunanistan'la işbirliğine gitmesi, Azerbaycan'la yaşanan Dağlık Karabağ sorununun çözümsüzlüğü ve sorunun kronikleşmesi sayılabilir (Aydın, 2010, s. 406-416). Diğer bir etken ise Ermenistan'ın tehcir hadisesini uluslararası kamuoyunda "soykırım" olarak tanıtarak Türkiye'den tazminat ve toprak talep etmesidir. Ermenistan'ın bu talebi iki ülke arasındaki ilişkinin çıkmaza girmesine neden olmaktadır (Görgülü, 2008, s. 13).

Türkiye zaman zaman Ermenistan ile ilişkileri normalleştirme yönünde adımlar atmışsa da Karabağ işgali, soykırım iddiaları ve kamuoyunun baskılarıyla çözüme ulaşılamamıştır. Bu yönüyle değerlendirildiğinde Türkiye halkının Ermenistan'a karşı bir ön yargısının olduğu ve Azerbaycan ile ilişkilerine daha fazla önem verdiğini ifade etmek mümkündür (Demir, 2005).

\subsection{Dağlık Karabağ Sorunu ve Türkkiye'nin Yaklaşımı}

Rusya'nın Dağlık Karabağ bölgesi içerisinde yer alan Nahçıvan ve Gence gibi bölgeleri işgaliyle (Kurat, 1999, s. 323) bölgenin etnik yapısında Ermenilerin sayısının artması yönünde değişiklikler meydana gelmiştir (Taşkıran, 1997, s. 1192). Karabağ'daki Ermeni nüfusunun Osmanlı İmparatorluğundaki çeşitli ayaklanma girişimlerine destek vermesiyle sorun Anadolu coğrafyasına sıçrayarak bir güvenlik meselesine dönüşmüştür (Gökçe, 2014, s. 2688). Bu bölgedeki nüfus değişimi Azerbaycan Türkleriyle Ermeniler arasında çatışmaları da beraberinde getirmiştir. Osmanlı İmparatorluğu Azerbaycan ile 1918 yılında dostluk anlaşması imzalayarak, Azerbaycan'a zor zamanlarında yardım etme sözü vermiştir (Gökçe, 2012, s. 61). Dolayısıyla Azerbaycan Türkleri ile olan dini, kültürel ve etnik bağlar siyasî olarak da tescillenerek resmiyete dökülmüştür. 
1. Dünya savaşının sonunda Osmanlı İmparatorluğunun yenilmesiyle, İmparatorluk, Azerbaycan bölgesinden çekilmek zorunda kalmıştır. Çekilme sonucu bölgede oluşan boşluk Sovyetler tarafından doldurularak, Bakü işgal edilmiştir. Sovyet Rusya'nın çökmesiyle birlikte Ermeniler'in Karabağ bölgesinde hak arayışları hız kazanmış ve ardından 1988 yılında Karabağ' daki Ermeniler, Ermenistan'a bağlandıklarını ilan etmişlerdir (Gökçe, 2014, s. 2691). Ermenilerin hareketleri Azerbaycan'da da milliyetçilik akımının güçlenmesine neden olmuştur. Örgütlü olarak hareket etmeye başlayan Azerbaycan halkı bağımsızlıklarını ilan ettikten sonra Karabă̆ bölgesinde Ermeniler ile çatışmalara girerek bölgeyi yeniden topraklarına katma yolunda adımlar atmaya başlamışlardır. Söz konusu çatışmalar günümüzde de devam etmektedir.

Türkiye ise Azerbaycan ile sahip olduğu etnik, kültürel ve dini ortaklıklar sebebiyle Dağlık Karabağ bölgesindeki yaşananlara hassasiyet göstermektedir. Bölgede yaşanan sorunlar aynı zamanda Türkiye-Ermenistan ilişkilerinde de belirleyici rollerden bir tanesini oluşturmaktadır. Ancak Türkiye söz konusu çatışmalarda 1992 yılına kadar tarafsız kalmayı tercih ederek, Ermenistan ile olan ilişkilerini geliştirmeyi tercih etmiştir. Buna karşılık Hocalı bölgesinde yapılan katliamlar Türkiye'nin Ermenistan ve Karabağ politikasında belirleyici olmuş ve sınır kapılarını kapatarak Azerbaycan tarafında yer almasını sağlamıştır (Demir, 2005, s. 120). 2000'li yıllarda Ermenistan ile normalleşme adımları çerçevesinde Türkiye ilişkilerin normalleşmesi ve sınır kapılarının tekrar açılmasında Karabağ'ın işgaline son verilmesini şart koşarak, Ermenistan'ın adım atmasını beklemiştir. Ancak söz konusu adım atılmamıştır.

\subsection{Söylem, İdeoloji ve Haber Metinleri}

Günümüzde haberi odak noktası alan çalışmalar iki ana sorun üzerine eğilmektedirler. Bunlardan birincisi gazeteciliğin tanımlanması diğeri ise gazetecilik pratiğinin yanlılık, manipülasyon ve çarpıtma vb. şeklinde konumlanmasıdır. Gazetecilik pratiğine dair yapılan makro çalışmalar onun sahiplik mekanizması, medya kuruluşlarının organizasyon yapısı ve kültürel modelleriyle ilgilenmektedir. Mikro çalışmalar ise "baskın haber değerleri”, "haber türleri" ve "kültürel etkilerin" haberlerin seçilme veya reddedilme sürecinde sahip olduğu rol üzerine odaklanmaktadır. Ancak bunların dışında kalan diğer bir grup ise haberlerin söylemi, haber metinlerinin ideolojik anlamı ve metinlerde kullanılan dilin yapısının da icelenmesi gerekliliği üzerinde durmaktadır (Doğru Arsa, 2004, s. 153). 
Bir olay haberleştirilirken pek çok diş etkenden etkilenmektedir. Eleştirel yaklaşımda bu etkilerin ideoloji, anlam, dil ve söylem olarak habere yansıdı̆̆ 1 iddia edilmektedir. $\mathrm{Bu}$ etkilerden dolayı haberin hakikati yansıtmadığı yani gerçekte olan olayla haber metninde aktarılan olayın farklı olduğu görüşü hakimdir. Ancak bu durum sadece eleştirel anlayışa has bir düşünce değildir. Ana akım medya çalışmalarının kurucularından birisi olarak kabul edilen Lippmann'da (1922, s. 345-347) bir yerlerde gerçekleşen olayla o olayın haberde aktarılan halinin kitle iletişim araçlarının süre ve alan sınırlılığı gibi bazı nedenlerle aynı olmadığını vurgulamaktadır. Her iki yaklaşımda da gerçekleşen olayla haberde o olayın aktarılan şeklinin farklı olduğu kabul edilmektedir. Ana akım liberal anlayışta bu farklılığın kitle iletişim araçlarının sınırlılıkları sebebiyle ortaya çıktığı kabul edilmekte, medya profesyonelleri tarafından olay çerçevelenerek ve belli özellikleri öne çıkarılarak süre ve alan olarak uygun hale getirilmektedir. Bu işlem yapılırken kitle iletişim aracının ayna görevi gördüğü ve nesnel olarak olayı aktardığı kabul edilmektdir. Ancak eleştirel yaklaşım bu çerçeveleme ve öne çıkarmanın nesnel olmadığını, kitle iletişim araçlarının ayna vazifesi görmediğini iddia etmektedir. Hatta çerçeveleme, öne çıkarma, nesnellik, sosyal sorumluluk ve haber değeri gibi meslek rutinlerinin söyleme yansıyan ideolojinin perdelenmesi için bir kamuflaj olduğunu haberin taraflı ve ideolojiyi yansıttığının anlaşılmasının önüne geçmek için kullanıldığını belirtmektedir. Kitle iletişim araçlarının mülkiyetine sahip olanların kendi iktidarlarını devam ettiebilmek için bu gücünü kullanarak diğer iktidarlarla ortak bir hegemonya oluşturduğu da kabul edilmektedir. Sonuç olarak eleştiel yaklaşımda kitle iletişim iletilerinin birilerini ideolojik olarak ikna etmek için üretildiği, iktidar veya güç odaklarına hizmet ettiği kabul görmektedir (Gerbner, 2014, s. $165)$.

Söylem, hem günlük hayatta kişilerarası iletişim sürecinde hem de yazılı ve görsel medya aracılığıyla sunulan içeriklerde ifade edilmek istenen mesajı belli bir algı ve çerçeveyle tanımlamaktadır. Söz konusu algılar ve çerçeveler kişilerin yaş, cinsiyet, gelir düzeyi, meslek ve eğitim gibi demografik özelliklerinden, kültür ve toplumsal yapılardan, siyasî ideolojilerden ve benzeri birçok belirleyici etkenden meydana gelmektedir (Güllüoğlu, 2012, s. 272). Diğer bir ifadeyle en basit olarak söylemi; "anlamın dil içinde hareket etmesiyle ortaya çıkan şey" (Sancar, 2014, s. 106) olarak tanımlamak mümkündür. Söylem tabiatı itibariyle ardalanında taşımış olduğu özellikler dolayısıyla yorum kuramının doğuşu ve gelişimiyle de yakından 
ilişkilidir. Bu nedenle söyleme dair yapılan tanımlamalar ve çözümlemelerde yorumla olan ilişkisi de göz önünde bulundurulmaktadır.

Söylemin etkilendiği parametreler göz önüne alındığında ideoloji ön plana çıkmaktadır. İdeoloji, sabit bir alan içerisinde katı şekilde sınırlandırılamayacağından her yerde zamana ve mekâna bağlı kalmaksızın oluşarak günlük hayatın her alanına etki edebilmektedir. Eagleton (2015, s. 18) ideolojiye dair, "toplumsal yaşamda anlamların, gösterge ve değerlerin üretim süreci”, "egemen bir siyasî iktidarı meşrulaştırmaya yardımcı olan yanlış fikirler”, "sistematik olarak çarpıtılan iletişim”, "söylem ve iktidarın birleşmesi”, “eylem yönelimli inanç kümeleri” ve "bireylerin toplumsal bir yapıyla ilişkilerini yaşadıkları onsuz olmaz ortam" gibi pek çok tanımı bir araya getirmektedir. Tanımlardan yola çıkıldığında ideolojinin toplumu oluşturan ortak değerlerde yer aldığını ifade etmek mümkündür.

Haber metinleri bir olayı haberleştirirken diğer bir ifadeyle haberdar etme görevini yerine getirirken ideoloji, anlam, dil ve söylem gibi birçok faktörden etkilenmektedir. Söz konusu faktörler aynı zamanda haberlerin gerçekliklerini de ifade etmektedir. Medyayla ilgili çalışmalarda yapı, anlam ve iktidarın bir bütün olarak ele alınmasının yanı sıra medyanın, toplum üzerinde bir tahakkümünün bulunduğu ve aynı zamanda bir temsil görevini de üstlendiği ifade edilebilir (Yağlı, 2007, s. 359). Bu kapsamda haberi anlama ve anlamanın sürdürülmesi kapsamında kültürel ve ideolojik kodlar ve sistemler de devreye girmektedir (İnal, 1996, s. 46). Dolayısıyla medyanın haberleri üretirken kendisine uygun olan kodları seçtiği ve bu kodlar aracılığıyla topluma sunuş gerçekleştirdiğini ifade etmek mümkündür. Bu nedenle "haber toplumsal gerçekliği inşa eder (kurar)" (Dursun, 2004, s. 37) ifadesi de haberlerdeki nesnellik ve tarafsızlığın olanaksız olduğuna dair göndermeyi ifade etmek için kullanılmaktadır.

Haber, gerçekliği inşa etme işlevinin de yüklenmesiyle birlikte; tarafsızlık, nesnellik, çeşitlilik ve özgürce ifade etme gibi ana akım liberal yaklaşımın sahip olduğu değerler eleştirel yaklaşım tarafından sorgulanmaya başlanmış ve dolayısıyla ideolojinin etkisinin de görünür kılındığı görüş hakim olmaya başlamıştır (Sözen, 1997, s. 53-54). Böylece liberal yaklaşımın sahip olmuş olduğu ve medyaya ithaf ettiği 4. güç olma özelliği de eleştirel yaklaşım tarafından hedef haline gelmiştir. Liberal yaklaşım içerisinde yer alan haberin nesnellik ve tarafsızlık ilkesi gibi ilkelerle haberi oluşturan olayların taraflarının ideolojilerden arınmış bir biçimde haber içerisinde yer alacağı görüşü savunulmaktadır. Bunun yanı sıra medya, hükümet 
uygulamalarını denetlemek ve toplumu tarafsız şekilde haberdar etme görevini yerine getirmelidir. Buna karşın eleştirel yaklaşım ise haberlerin aktarımında kullanılan dilin ve kendi başına aktarım işlevinin habere konu olan olayın tarafsız ve nesnel biçimde aktarılmasının önündeki engel olarak kabul etmektedir. Bu nedenle haber metinlerini üreten medyanın yapısı, haberi üreten gazetecinin kimliği, görüşü, ideolojisi, kullandığı cümleler ve dil, tarafsızlık ve nesnellik ilkesinin işlemesini engellemektedir (Dursun, 2001, s. 128).

Haber metinlerinin temelini oluşturan dil, toplumsal sürecin bir öğesi olarak kabul edilmektedir. Dil, ideolojinin bir yansımasıdır ve ideoloji tarafından kuşatılmıştır. Dolayısıyla ideolojinin dilde ve sözcük seçimlerinde yer aldığı ifade edilebilir (Özer, 2011, s. 55-56). Haberde ideolojinin yer alması ve haber metinlerinin ideolojiyi yeniden ürettiği ve eleştirel yaklaşımın da savunduğu görüşe göre "dil nötr olamaz; çünkü dil insanların dünya görüşlerini yapılandırır ve ondan yansır" (Özer, 2011, s. 61). Bu nedenle haberlerin sunumunun tarafsız olması mümkün değildir. İdeolojinin haberlere etki etmesi haberlerin dilinde yanlılık şeklinde kendisini göstermektedir. Söz konusu yanlılığın boyutu medya kuruluşları arasında farklılık gösterse de her medya kuruluşunda bir biçimde veya çeşitli boyutlarda varlığını göstermektedir. Örneğin, herhangi bir olayın farklı çizgilerdeki medya kuruluşları tarafından sunuluşunda tercih edilen sözcükler ideolojik yansımanın ürünü olarak kabul edilmektedir. Bu durumda medya kuruluşlarının ideolojik bir atmosferden etkilendiği sonucuna ulaşılmaktadır (Özer, 2011, s. 6162). Dil aynı zamanda anlamın tamamlayıcısı pozisyonundadır. Toplumsal pratikler ve ideoloji tarafından şekillenen dil, haber metinlerine yansıyarak ideoloji ve hegemonyanın yeniden üretilmesinde önemli role sahiptir (Hall, 1994, s. 88-97).

Haber metinlerini oluşturan sözcükler, güç ve iktidar ilişkileriyle birlikte ideolojik yansımanın görünür kılındığı bir başka yerdir. Bu kapsamda haber metinlerinde tercih edilen sözcükler belirli bir ideoloji ve tavrı yansıtmaktadır. Dil ve söylem, toplumsal alandaki güç/iktidar ilişkilerinin dayanak noktasını oluşturan cinsel, etnik ve dinsel farklılıkların yansıdığı bir çekişme alanıdır. Söz konusu çekişme söyleme ilişsin bir kavramdır. Bu nedenle sözcüklerin anlamı ve vurgusu söylemler içerisinde oluşmaktadır (İnal, 1996, s. 119). Bu yüzden haber metinlerini oluşturan sözcükleriyle dil ve söylem haber metinlerinde başat olanın ideoloji olmasını sağlamaktadır. Söz konusu oluş da haber metinlerinin yanlılığını oluşturmaktadır. Medya profesyonelleri tarafından haber metinleri içerisine yerleştirilen 
sözcükler haberin alıcısı konumundaki okuyucuların ilgili yanlılığı alımlamasını da sağlamaktadır (Yağl1, 2007, s. 360).

İdeolojiyi üreten ve yansıtan konumundaki medya ve haberler aynı zamanda kendi konumlanışlarını da belirleyebilmek için ideolojiye ihtiyaç duymaktadırlar. Medya, kitleleri etkileyebilme gücüyle birlikte aynı zamanda egemen güç konumundaki devletler ve siyasî iktidarlar açısından da araçsallaşarak hakim ideolojiyi yansıtma veya empoze etme görevini de üstlenmektedir (İnal, 1996, s. 39). Bu bağlamda Althusser'in devletin ideolojik aygıtı olarak tanımladığı medya, egemen güç konumundaki devlet ve iktidar tarafından fizikî güç kullanımı diğer bir ifadeyle baskı aygıtlarına gerek kalmadan toplumda neyin ön plana çıkması veya neyin gündem dışında kalmasına da yardımcı olmaktadır (Althusser, 2000, s. 33-36). Althusser (2000, s. 43), bir siyasal aygıt olarak devletin bireyleri kendi ideolojisine doğrudan veya dolaylı olarak uydurmak için basını kullandığını ifade etmektedir. Egemen olan gücün maddi olanakları da elinde bulundurması medyanın ve gazetecilerin yanlılığı tartışmasını gündeme getirmektedir. Bu bağlamda siyasî, ekonomik, baskı aygıtları ve diğer seçkinlerin söylemleri, medya ve haber metinleri aracılığıla meşruiyet oluşturma ve toplumda rıza üretme aracı olarak araçsallaşabilmektedir (İnal, 1995, s. 112-113). Bu nedenle medya, iktidarın ve ekonomik gücü elinde bulunduran güçlerin egemenliğini pekiştirmektedir. Dolayısıyla medya, egemen güç konumunda bulunanın sahip olmuş olduğu ideolojiyi benimsetme, yayma ve meşrulaştırma görevini de yerine getirmektedir. Sonuç olarak haber metninin içerisinde kullanılan her sözcüğün, kavramın, cümlenin, görselin ve dilin belirli bir anlama ve ideolojik yansımaya sahip olduğu ifade edilebilir.

\section{YÖNTEM}

Literatürde söyleme dair eleştirel ve eleştirel olmayan şeklinde iki ana yaklaşım bulunmaktadır. Eleştirel olan söylem çözümlemesi, politik olanı, iktidar ve güç ilişkilerini, kültürel etkileri, sosyal hayatı ve ideolojileri de tanımlaması açısından eleştirel olmayan söylem modelinden ayrılmaktadır (Fairclough, 1992, s. 12). Eleştirel söylem analizinin öncüsü van Dijk (1993, s. 252) eleştirel söylem analizinin, sosyo-politik konumunu, bakış açılarını, amaçlarını ve prensiplerini ortaya koymasından dolayı diğer söylem analizlerinden ayrıldığını ifade 
etmektedir. Bu nedenle eleştirel söylem analizinin bir olaydaki güç ilişkileri, sosyal, kültürel durum ve eşitsizliklerle ilgilendiğini ifade etmek mümkündür.

Eleştirel söylem analizi hâkim sınıfın medya aracılığıyla bilgiyi kontrol etmesi, bu kontrol sayesinde de bilginin toplum tarafından algılanışına etkisinin bulunduğundan hareket etmektedir. Özellikle metinlerin içerisinde doğal olarak yer alan veya bilinçli şekilde yerleştirilen ifadelerdeki ideolojik yansımayı da ortaya çıkarmasından dolayı ayrıca önemlidir (Özer, 2015, s. 204). Bu nedenle eleştirel söylem analizi toplum içinde yer alan kültürel, sosyal, siyasî ve ideolojik sorunların açığa çıkarılmasına büyük katkılar sunmaktadır. Dolayısıyla söylemi meydana getiren ve yukarıda bahsedilen faktörler söylemi bireysel veya toplumsal anlamda göstergelerin de barındırıldığı bir temsil olarak konumlandırmaktadır. Söz konusu konumlandırılış söylemin üretilişindeki ideolojik, kültürel, sosyolojik ve siyasî parametreler gibi parametrelerin aynı zamanda söyleme maruz kalanlar tarafından nasıl algılandığını da önemli k1lmaktadır (Büyükkantarcıoğlu, 2012, s. 164).

Eleştirel söylem analizi kapsamında ideoloji, "grup üyelerinin sosyal temsillerinin bir karşılığ1 olarak düşünülmektedir” (Yardım \& Doğruel, 2019, s. 140). Van Dijk ideolojinin günlük yaşantımızda ve konuşmalarımızda söylem düzeyinde ortaya çıktığını ifade etmektedir. Bunun yanı sıra ideolojiyi toplumda grup ve kültürel ortamda paylaşılan değerler olarak vurgulamaktadır (Özer, 2011, s. 52). Dolayısıyla ideoloji hakkındaki genel tanımların içerisinde yer almaktadır. Ancak ideolojiyi bireysel konumdan alarak gruplar tarafından paylaşılan konumuna yerleştirmektedir. Bunun yanı sıra haber metinlerini, gazetecilerin de toplumun bir parçası olmalarından dolayı toplumsal söylemin bir parçası olarak kabul etmektedir (Van Dijk, 1988, s. 9). Bu nedenle ideolojinin bireysel olarak ortaya çıktığı düşünülse de grubun etkisinin göz ardı edilemeyeceğini ve haber metinlerinde yeniden üretildiğini de ifade etmektedir (Van Dijk, 1988, s. 205).

Bütün bu bilgiler 1şığında Özer (2000, s. 80-82) van Dijk'ın eleştirel söylem analizini bütünleştirerek aktarmaktadır. Bu bağlamda eleştirel söylem analizi makro ve mikro yapı çözümlemesi olarak iki ana bölümde ve her bölüm kendi alt bölümlerinden oluşacak şekilde formüle edilmektedir. Makro yapı tematik ve şematik çözümleme olarak iki alt başlığa ayrılmaktadır. Tematik çözümlemede başlıklar, spot veya haber girişleri analiz edilmektedir. Başlıklar, spot veya haber girişleri hem olayların sunuşundaki ideolojik yapının ortaya çıkması hem de habere konu olan olayın özetlenmesi açısından önemlidir. Gazete okuyucusunun ilk 
başta başlık ve spot veya haber girişleriyle karşılaşır. $\mathrm{Bu}$ nedenle ilgili bölümlerin incelenmesinde, başlıkların birbirleriyle olan ilişkisi, başlıkların spot veya haber girişiyle olan ilişkisi, spot veya haber girişinde haberin özetinin verilip verilmediğine bakılmaktadır. Şematik çözümlemede bağlam ve ardalan bilgisi, ana olayın sunumu ve sonuçlarıyla haberin beslenildiği kaynaklara bakılmaktadır. Şematik inceleme haberin sunuluşunda katılan yorumlar nedeniyle ideolojinin ve kültürün yansımalarını da içermektedir. Mikro yapı çözümlemesinde cümlelerin sentaktik açıdan uzunluğu kısalığı, öznelerin etken veya edilgen olarak konumlandırılışı incelenmektedir. Kelime seçimleri ise mikro yapı çözümlemesinde ideolojinin daha belirgin olarak ortaya çıktığı yerdir. Bu yüzden seçilen kelimeler, gazetecinin veya gazetenin ideolojisini de net biçimde ortaya koymaktadır. Retorik bölümünde ise haber metnindeki ifadeler veya iddiaların kanıtlanması için istatistiki veriler, fotoğraflar ve veriler gibi kaynakların kullanılıp kullanılmadığının analiz edildiği bölümdür. Retorik bölüm okuyucunun ikna edildiği bölümdür.

Çalışmada Ermenistan-Azerbaycan arasında Karabağ bölgesinde 27.09.2020 tarihinde yeniden başlayan çatışmalar ve ateşkes anlaşmasının imzalandığı 10.10.2020 tarihine kadarki süreçte farklı ideolojilere sahip olan Cumhuriyet gazetesindeki 9 haber, Sabah gazetesindeki 11 haber ve Türkgün gazetesindeki 13 haber van Dijk’ın eleştirel söylem çözümlemesi yöntemine göre incelenmiştir. Çatışmaların yeniden başladığı ve ateşkes anlaşmasının imzalandığı tarihler çalışmanın sınırlılığını oluşturmaktadır. Diğer bir sınırlılık ise ilgili gazetelerdeki haberlerin birinci sayfa haberlerinin incelenmesidir. Haber incelemelerinde birinci sayfaların tercih edilmesinde ana sebep mesajın ve ideolojik yanlılığın bu sayfada daha belirgin olmasıdır.

\section{BULGULAR VE YORUM}

\subsection{Makro Yapı İncelemesi}

- Tematik Yapı İncelemesi

a. Haber Başlıkları

\section{Cumhuriyet Gazetesi Bașlıkları}

Üst Başlık: “Azerbaycan, Ermenistan İşgalindeki 7 köyü geri aldı” (Cumhuriyet28.09.2020) 
Başl1k: "Sınırda Savaş" (Cumhuriyet-28.09.2020)

Başlık: “Ateşkes için 'çekilin’ şartı” (Cumhuriyet-29.09.2020)

Başlık: "Türkiye-Rusya diyaloğu çözer" (Cumhuriyet-30.09.2020)

Başlık: “Olayların Ardındaki Gerçek” (Cumhuriyet-01.10.2020)

Üst Başlık: "Karabağ Gerilimi” (Cumhuriyet-03.10.2020)

Başlık: "Moskova ile Anlaşmazlık” (Cumhuriyet-03.10.2020)

Başlık: “Gence’ye Saldırı” (Cumhuriyet-05.10.2020)

Üst Başlık: 'Kafkaslardaki çatışmaya sessiz kalan Moskova'nın öncelikleri 'şimdilik' farkl1" (Cumhuriyet-07.10.2020)

Başl1k: "Rusya arada kaldı" (Cumhuriyet-07.10.2020)

Üst Başl1k: "Paşinyan'a beklediği desteği vermeyen Rusya, Karabağ' da ateşkes istedi" (Cumhuriyet-08.10.2020)

Başlık: "Putin sınırı çizdi” (Cumhuriyet-08.10.2020)

Başlık: “Karabağ Hattında Ateşkes Yakın” (Cumhuriyet-10.10.2020)

$\underline{\text { Sabah Gazetesi Bașlıkları }}$

Başlık: “İşgalci Ermenistan’a Azeri Tokadı” (Sabah-28.09.2020)

Alt Başlık: “Tüm Gücümüzle Yanınızdayız” (Sabah-28.09.2020)

Başlık: "İşgal Bitsin Barış Gelsin” (Sabah-29.09.2020)

Alt Başlık: "YPG Destekli Ermeni Mevzileri Yerle Bir” (Sabah-29.09.2020)

Başl1k: “İşte Ermenistan Cephesindeki PKK'lılar” (Sabah-30.09.2020)

Başlık: “Azerbaycan Tarih Yazıyor” (Sabah-01.10.2020)

Başl1k: "Haydut Devlet Karabağ’1 Terk Et”" (Sabah-02.10.2020)

Alt Başl1k: "Ermenistan Sivilleri Vuruyor" (Sabah-02.10.2020)

Üst Başlık: "Ermeni Birlikleri Silahlarını Bırakıp Kaçıyor” (Sabah-03.10.2020)

Başl1k: "Büyük Bozgun” (Sabah-03.10.2020) 
Başlık: “Ateş Etmeyin Teslim Oluyoruz” (Sabah-04.10.2020)

Üst Başlık: “Azerbaycan Adım Adım Zafere” (Sabah-05.10.2020)

Başlık: “Ermeniler’den Alçak Saldırı” (Sabah-05.10.2020)

Başlık: “Karabağ’da 27 Y1l Sonra Ezan Sesi” (Sabah-06.10.2020)

Başlık: “Aşs Olsun (yaşasın) Türk Halkı” (Sabah-07.10.2020)

Başlık: “Tabana Kuvvet Kaçıyorlar” (Sabah-08.10.2020)

Türkgün Gazetesi Bașlıkları

Başlık: “Azgın Ermeni’ye Azerbaycan Tokadı” (Türkgün-28.09.2020)

Alt Başlık: “Ermenistan Büyük Tehdit” (Türkgün-28.09.2020)

Alt Başlık: “Kanımızla, Canımızla Yanlarındayız” (Türkgün-28.09.2020)

Başl1k: “Ermenistan Köşeye Sıkıştı: Hesap Vakti” (Türkgün-29.09.2020)

Alt Başl1k: "Işgal ettiğgin yerleri terk et” (Türkgün-29.09.2020)

Başlık: “Tek Çözüm Karabağ'ın Azatlığı” (Türkgün-30.09.2020)

Başlık: “Azerbaycan Ne İsterse Yaparız” (Türkgün-01.10.2020)

Başl1k: “Şimdi Netice Zamanı” (Türkgün-02.10.2020)

Başlık: "Karabağ Azat Olmadan Bu Ateş Kesilmez” (Türkgün-03.10.2020)

Başlık: “30 Yıl Daha Bekleyemeyiz” (Türkgün-04.10.2020)

Başl1k: “Nahçivan Azerbaycan'a Katılmalı” (Türkgün-05.10.2020)

Başl1k: "Ermenistan Terör Devleti” (Türkgün-06.10.2020)

Alt Başl1k: “Türkiyesiz Olmaz!” (Türkgün-06.10.2020)

Alt Başlık: “Türk SİHA’ların Başarısı” (Türkgün-06.10.2020)

Başl1k: “Ya Çekilecekler Ya Ezilecekler” (Türkgün-07.10.2020)

Üst Başlık: "Ermeni Bir Kadından, Azerbaycanlı Askerlere Anlamlı Karşılama" (Türkgün-08.10.2020)

Başlık: "Evinize Hoş Geldiniz” (Türkgün-08.10.2020) 
Başl1k: "Ermenistan-PKK Terör Ortakları” (Türkgün-09.10.2020)

Başlık: "Azerbaycan, Orduya Son ve Kesin Hedefi Gösterdi: İstikamet Karabağ" (Türkgün-10.10.2020)

Eleştirel söylem çözümlemesinde van Dijk'1n (1988, s. 226), gazete okurları ilk olarak başlıkla karşılaşmakta ve olayla ilgili en önemli bilgi başlıklarda verilmekte önermesinin her üç gazetede de doğrulandığg görülmektedir. Üç gazete de başlıklarında haberin ne olduğuyla ilgili bilgiyi okuyucuyla paylaşmakta ve onu bilgilendirmektedir. Başlıklarda dikkat çeken unsur her üç gazetenin de Karabağ'ın Ermenistan işgalinde olduğunu kabul ederek, "işgal altındaki” ve "işgal” ifadelerini kullanmaktadır. Dikkat çeken diğer bir nokta ise Cumhuriyet gazetesinin Karabă̆ sorununun çözümüne dair başlıklarının bulunması ancak Sabah gazetesinde ise devamlı olarak Azerbaycan'ın galibiyetleri, Ermenistan'ın yenilgisi ve “ezan sesi” gibi kültürel ve dini motifleri kullanarak Azerbaycan ile olan kültürel ve dini bağlara gönderme yapmasıdır. Türkgün gazetesi ise açık bir şekilde Azerbaycan'a destek vermekte ve süreçteki hamlelerini yüceltirken Ermenistan açık bir şekilde düşman olarak gösterilerek alçaltılmaya çalışılmaktadır. Burada Sabah ve Türkgün gazetelerinin başlıklarındaki ifadelerin kimi zaman aynı olduğu ve söylemin aynı şekilde biçimlendiği görülmektedir.

\section{b. Haber Girişleri}

Haber girişleri haber metninin önemli bir parçasını oluşturmaktadır. Okuyucunun ilgisini çekebilmek amacıyla başlıklardan daha küçük ama haber metninden daha büyük puntoyla yazılmaktadır. Haber girişleri başlıkta yer alan konuyu özetlemesi ve haberin ana fikrini aktarması açısından ayrıca önemlidir (Özer, 2000, s. 84). İncelenen gazetelerde haber girişlerinin okuyucuyu bilgilendirmek için konuyu özetlediği ve haberlerin ana fikrini aktardığ görülmektedir.

\section{Cumhuriyet Gazetesi Haber Girișleri}

“Ermenistan’ın sivil yerleşim yerlerini hedef almasının ardından Azerbaycan, 1992'de işgal edilen Karabağ’a yönelik harekât başlattı” (Cumhuriyet-28.09.2020)

“Azerbaycan'a göre yüzlerce, Ermenistan'a göre ise 31 adet Ermeni askeri öldü” (Cumhuriyet-29.09.2020)

“Azerbaycan-Ermenistan çatışmasını değerlendiren Uluç Özülker, gerilimi TürkiyeRusya diyaloğunun çözeceğini söyledi” (Cumhuriyet-30.09.2020) 
“Ermeni ordusu, Karabağ toprakları üzerinden Azerbaycan’a saldırdı. Bunun karşılığını da gördü ve Azerbaycan ordusu kritik bölgelerdeki önemli köyleri Ermeni işgalinden kurtardı” (Cumhuriyet-01.10.2020)

“Çavuşoğlu-Lavrov görüşmesine ilişkin Moskova'nın 'iki bakan da Karabağ’ da derhal ateşkesin sağlanması gerektiğini vurguladı' ifadesini Ankara doğrulamadı” (Cumhuriyet03.10.2020)

“Azerbaycan'da sivillerin yaşadığı yerler füzelerin hedefi oldu. Gence’ye saldırıda bazı binalar yıkıldı, bir üssün hasar gördüğü iddia edildi. Mengeçevir’e füze, Terter ve Beylegan’a top atışı yapıldığı belirtildi. Saldırılarda en az 22 kişinin öldüğü duyuruldu" (Cumhuriyet05.10.2020)

“Azerbaycan'la Ermenistan arasındaki çatışmalarda, şimdiye kadar Karabağ’da 'anahtarı elinde tutan ülke' Rusya göreceli olarak sessizlik içinde.” (Cumhuriyet-07.10.2020)

“Ermenistan'ın işgali altıdaki Karabağ hattında çatışmalar sürerken ağırlığını koymaya başlayan Rusya lideri Putin, taraflara “en kısa zamanda ateşkes” çağrısı yaptı" (Cumhuriyet08.10.2020)

“Ermenistan işgali altındaki Dağlık Karabağ ve çevresindeki kentlerde çatışmalar sürerken Rusya devreye girdi” (Cumhuriyet-10.10.2020)

\section{$\underline{\text { Sabah Gazetesi Haber Girișleri }}$}

“Azeri köylerini ağır toplarla vuran Ermenistan'a derhal cevap veren Azerbaycan, 30 yıldır işgal altıdaki Karabağ'da 7 köyü geri aldı" (Sabah-28.09.2020)

“Başkan Erdoğan: Ermenistan'ın işgal ettiği Azerbaycan topraklarını derhal terk etmesiyle bölge yeniden barışa ve huzura kavuşacak" (Sabah-29.09.2020)

"Yüzlerce teröristin Azerbaycan'a karşı savaşmak için Ermeni saflarına katıldığı saptand1" (Sabah-30.09.2020)

“İşgal altındaki topraklarını tek tek geri alan Azerbaycan Ermeni cephesini yerle bir etti. 2300 askerini kaybeden Ermenistan ordusu mevzilerini bırakarak kaçmaya başladı” (Sabah01.10.2020)

"Başkan Erdoğan: Kalıcı barışın tek yolu, Ermenilerin işgal ettikleri her karış Azerbaycan toprağından geri çekilmelerinden geçiyor” (Sabah-02.10.2020)

“Azerbaycan ordusu, Türk SİHA'larıyla Ermeni hedeflerini darmadağın ediyor. Tarihi kayıplar veren Ermenistan güçleri mevzilerini terk ederek kaçıyor” (Sabah-03.10.2020) 
“Azerbaycan ordusu vuruyor, ağır kayıplar veren Ermenistan güçleri geri çekiliyor. Karabağ'daki birçok bölgede Ermeni askerleri peş peşe teslim bayră̆ını çekiyor” (Sabah04.10.2020)

“Azerbaycan ordusu Dağlık Karabağ’da 10 bölgeyi Ermeni işgalinden kurtard1. Zafer, ülkede sevinç gösterileriyle kutlanıyor” (Sabah-05.10.2020)

“Azerbaycan Ordusu Dağlık Karabağ’da 25 yerleşim yerini Ermeni işgalinden kurtardı. Bu yerlerde yeniden ezan sesleri yükseliyor" (Sabah-06.10.2020)

“Azerbaycanlılar, Türkiye'nin desteğine duacı: Aşk olsun kardeş Türk halkına ve Cumhurbaşkanı Erdoğan'a” (Sabah-07.10.2020)

"Azerbaycan ordusunun bozguna uğrattığı Ermeni güçleri mevzilerini terk edip kaçıyor" (Sabah-08.10.2020)

\section{Türkgün Gazetesi Haber Girișleri}

"Ermeniler, Azerbaycan sınırındaki sivil yerleşim birimlerine saldırdı. Azerbaycan ordusu, anında karşı1lık verdi. 6 köy, Ermenistan işgalinden kurtarıldı” (Türkgün-28.09.2020)

“Ermenistan’ın sınırda yaptığı saldırıya misliyle cevap veren Azerbaycan'da kısmi seferberlik ilan edildi. Savunma Bakanlığı, sivil yerleşim birimlerine ateş açmaya devam eden Ermenistan ordusunu son kez uyard1” (Türkgün-29.09.2020)

'BM ve uluslararası hukukun, 'Karabağ, Azerbaycan toprağıdır' kararını hayata geçirmelerinin zamanı geldi. Dışişleri Bakanı Çavuşoğlu, bu sorunun tek çözümünü şöyle açıkladı: Ermenistan, Azerbaycan topraklarından çekilecek" (Türkgün-30.09.2020)

“Dışişleri Bakanı Mevlüt Çavuşoğlu, 'Sorun çözülmedikçe Ermenistan cesaretleniyor' dedi. Çavuşoğlu, Türkiye'nin devlet olarak da, millet olarak da Azerbaycan'ın yanında olduğunu dile getirdi” (Türkgün-01.10.2020)

“Cumhurbaşkanı Erdoğan, Ermenistan'1 kastederek, 'Bu haydut devlete destek verenleri, kendilerine insanlığın ortak vicdanı önünde hesap konusunda ikaz ediyorum. Ateşkes kabul edilebilir değildir’ dedi.” (Türkgün-02.10.2020)

“Azerbaycan ordusu, işgal altındaki Karabağ’a doğru ilerlerken, ağır kayıplar veren Ermenistan ateşkes çağrısı yaptı. Milli Savunma Bakanı Akar, ateşkes çağrılarının samimi ve inandırıcı olmadığını söyledi” (Türkgün-03.10.2020)

“Azerbaycan Cumhurbaşkanı İlham Aliyev: Biz, 'durun, çalışacağız, müzakere yürüteceğiz, yardım edeceğiz' gibi beyanları dinleyecek durumda değiliz. Geçti o günler. Artık, sorun şimdi çözülmelidir” (Türkgün-04.10.2020) 
“MHP lideri Devlet Bahçeli: Nahçivan'la birleşme sonucunda tek ses, tek nefes, tek yürek halinde zalime ve düşmana karşı mücadele edilecektir. Ermenistan zalimdir, canidir, döktüğü kanda boğulmalıdır” (Türkgün-05.10.2020)

"Cephede arkasına bakmadan kaçan, yalan ve iftiralarla dünyayı kandırmaya uğraşan Ermenistan, yine Azerbaycan'ın ikici büyük kenti olan Gence'ye ve sivillere saldırıp, insanlık suçu işledi” (Türkgün-06.10.2020)

“MHP lideri Devlet Bahçeli: Azerbaycan'ın, işgal edilen topraklarının azatlığını temin etmeden durması imkânsızdır. Mütecaviz düşmanın beli kırılmadan, askeri başarı siyaseten tasdik edilmeden kurulacak her masa tavizdir" (Türkgün-07.10.2020)

“Azerbaycan ordusu ilerleyişini sürdürüyor. Dağlık Karabağ’da işgalden kurtarılan köyde yaşayan bir Ermeni kadın, Azerbaycanlı askerlere 'evinize hoş geldiniz' diyerek, dünyanın görmezden geldiği bir hakkı teslim etti” (Türkgün-08.10.2020)

“Türk milletine karşı ihanet, cinayet ve kalleşlikte yaptıkları iş birliğini Karabağ’ da da sürdürüyorlar” (Türkgün-09.10.2020)

“Azerbaycan Savunma Bakanlığı Sözcüsü Yarbay Anar Eyvazov, işgalden kurtardıkları yerlerden bir adım bile geri çekilmediklerini, Karabağ'ı alıncaya kadar durmayacaklarını söyledi” (Türkgün-10.10.2020)

Haber girişleri incelendiğinde Cumhuriyet gazetesinin diyalog ve ateşkesten yana olduğu görülmektedir. Bunun yanı sıra kültürel, dini ve etnik vurgunun olmadığ 1 da ifade edilebilir. Ayrıca sivil yerleşim yerlerine yapılan saldırılar da okuyucuya aktarılmaktadır. Ancak Sabah gazetesinde ideolojik olarak bir konumlanma görülmektedir. Özellikle Azerbaycan halkının Cumhurbaşkanı Erdoğan'a ve Türkiye'ye teşekkür etmeleri, Azerbaycan'ın saldırılarında Türk SİHA'larının kullanıldığının vurgulanması ve Ermenistan'ın mağlubiyet yaşadığı okuyucuya aktarılmaktadır. Sabah gazetesinin ek olarak PKK'lıların da Ermenistan'a yardım ettiğini ifade ederek Türkiye nezdinde terör ve Ermenistan'ı beraber konumlandırdığg görülmektedir. Türkgün gazetesi ise Cumhuriyet ve Sabah gazetelerinden farklı olarak Devlet Bahçeli’nin sözlerine de yer vermektedir. Bu nedenle gazetenin ideolojik olarak konumlandığg görülmektedir. Bunun yanı sıra Türkgün gazetesinin Sabah gazetesi ile benzer şekilde terör ve Ermenistan'1 beraber konumlandırdığ görülmektedir. Buna sebep olarak siyasi alandaki ittifakın etkisi gösterilebilir. Üç gazetenin ortak yönü ise Karabağ’1 tanımlarken işgal edilmiş topraklar olarak belirtmeleridir. Üç gazete haber girişlerinde olayların ne olduğunu okuyucuya aktarmaktadır. 


\section{c. Fotoğraflar}

Fotoğraflar haberlerin inandırıcılığı için hem bir retorik unsur hem de görsel olarak zihne gönderme yapmaktadır. Üç gazete incelendiğinde Cumhuriyet gazetesinin sivillerin hedef alındığı saldırılarda olay yerlerinden fotoğraflar kullandığı ve ateşkes görüşmelerinde Rusya, Azerbaycan ve Ermenistan dışişleri bakanlarının bulunduğu yuvarlak masa fotoğrafını kullandığı görülmektedir. Diğer haberlerinde fotoğraf kullanmamıştır.

Sabah gazetesinin ise her haberini birden fazla fotoğrafla desteklediği görülmektedir. Özellikle 28.09.2020, 29.09.2020 ve 02.10.2020 tarihli haberlerde Cumhurbaşkanı Erdoğan plana çıkartılmıştır. Diğer yandan PKK'lıların Ermenistan'a destek verdiği yönündeki 30.09.2020 tarihli haberinde PKK'lıların fotoğrafları kullanılmış ve Azerbaycan halkının Türkiye’ye teşekkür ettiği 07.10.2020 tarihli haberde ellerinde Türkiye bayrakları da olan Azeriler görsel olarak kullanılmıştır. Bunun yanı sıra Karabağ' da geri alınan bir bölgede ezan okuyan askerin yer aldığı 06.10.2020 tarihli fotoğraf kullanılmıştır. Sabah gazetesinin kullandığı görsellerde Erdoğan vurgusu ideolojik konumlanmayı göstermektedir. Bunun yanı sıra PKK'lıların fotoğraflarıyla Türkiye halkına ve dünyaya terör örgütünün Ermenistan'a destek verdiği intibası oluşturulmaya çalışılmıştır. Azerilerin Türk Bayrağı ile sevinç gösterilerinde bulunduğu görseller aracılığıyla Azerbaycan ile Türkiye arasındaki kültürel bağ1 ve "tek millet, iki devlet" vurgusu öne çıkartılmıştır. Karabağ'da geri alınan köylerde ezan okuyan asker fotoğrafıyla da Türkiye ile olan dini bağın ön plana çıkartıldığını ifade etmek mümkündür.

Türkgün gazetesi ise 09.10.2020 tarihli haber dışındaki haberlerin tamamında fotoğraf kullanmıştır. 28.09.2020 tarihli haber görselinde Cumhurbaşkanı Recep Tayyip Erdoğan, MHP Genel Başkanı Devlet Bahçeli ve İlham Aliyev’in fotoğrafları beraber kullanılmıştır. Bunun yanı sıra TSK ve Azerbaycan ordularından iki askerin tokalaştığı görselin arkasında Türkiye ve Azerbaycan bayrakları yer almaktadır. Devlet Baçelinin tek olarak yer aldığ 05.10.2020 ve 07.10.2020 tarihli fotoğraflarıyla ideolojik olarak konumlanmaktadır. Bunun yanı sıra 06.10.2020 tarihli haberde fotoğraf olarak bozkurt işareti yapan askerlerin bulunması ideolojik konumlanmanın ortaya çıktığı diğer görseldir. Ayrıca 29.09.2020 ve 02.10.2020 tarihli haberleri fotoğraflarında Cumhurbaşkanı Erdoğan ön plana çıkartılmıştır. 30.09.2020 tarihli haberde Azerbaycan'daki sivil yerleşim yerlerinin Ermenistan tarafından hedef alındığı görsel kullanılmıştır. 01.10.2020 tarihli haber görselinde Dışişleri Bakanı Mevlüt Çavuşoğlu'nun fotoğrafı yer almaktadır. 03.10.2020 tarihli haberde devrilmiş Ermenistan askeri aracı yer 
almaktadır. 04.10.2020 tarihli haberde fotoğraf olarak esir alınmış olan Ermenistan askerleri yer almaktadır. 08.10.2020 tarihli haberde Azerbaycan askerlerini karşılayan Ermeni kadın görseli kullanılmıştır. Son olarak 10.10.2020 tarihli haberde Azerbaycan tankları ve bayrağının yer aldığı fotoğraf kullanılmıştır. Türkgün gazetesindeki fotoğraflarda Azerbaycan ile dini, milli ve kültürel yakınlığın etkisi hissedilmekte, bazı fotoğraflarda yer alan siyasi figürlerin seçiminde de ideolojik yansımalar açıkça görülmektedir.

- Şematik Yapi İncelemesi

a. Ana Olayın Sunumu ve Sonuçları

“Karabağ’da ilk Türk-Ermeni çatışması 1905 yılında oldu. 1988 yılında Karabağ’daki Ermeniler, Sovyetler Birliği içinde ilk isyanı çıkararak Karabă̆ Ermenileri Ulusal Konseyini kurdu ve Azerbaycan'dan ayrılarak Ermenistan'a bağlandığını ilan etti” (Cumhuriyet01.10.2020)

“Moskova'nın tavrını Batı yanlısı Paşinyan iktidarına bağlayanlar var" (Cumhuriyet07.10.2020)

'Putin 'Kolektif Güvenlik Antlaşması Örgütü' kapsamında Ermenistan'a karşı sorumluluklarımız var. Ama çatışmalar, Ermenistan topraklarında değil” (Cumhuriyet$08.10 .2020)$

"Aliyev, 'biz kan dökülmesin istiyoruz. Topraklarımızdan çıkın. Tarihi şansı kaçırmayın' çağrısı yaptı" (Cumhuriyet-10.10.2020)

"Ermenistan Ordusunun ağır bombardımana tuttuğu Azeri köylerinde birçok sivil öldü ve yaralandı. Karşılık veren Azeri ordusu Ermeni birliklere ait çok sayıda askeri teçhizat ve tesisi yok etti." (Sabah-28.09.2020)

“Terör örgütü PKK'nın kanlı eli, bu kez Azerbaycan-Ermenistan cephesine uzandı. Örgüt Azerbaycan' karşı Ermeni dostlarının safında savaştırmak için sıcak çatışmaların sürdüğü Dağlık Karabă̆ bölgesine 300’den fazla terörist gönderdir” (Sabah-30.09.2020)

“Ermenilerin Karabağ’’ işgaline ve sivil katliamlarına karşı kör, sağır, dilsiz kalanların bu tavrı da ikiyüzlülüktür. Bu haydut devlete destek verenleri, insanlığın ortak vicdanı önünde hesap sorulacağı konusunda uyarıyorum" (Sabah-02.10.2020) 
“Karabağ’da oyunun kurallarını ise Azerbaycan ordusunun kullandığı Bayraktar TB2 silahlı İnsansız Hava Aracı (SİHA) belirliyor” (Sabah-03.10.2020)

"Yol kenarlarında ve arabalarda yaşayan Azeriler, SABAH aracılığıyla Türkiye’ye mesaj yolladı: Reyhan Şirinova: Bu savaşta kardeş Türkiye bize çok destek oldu. Aşk olsun Türk halkına, aşk olsun Cumhurbaşkanı Erdoğan'a” (Sabah-07.10.2020)

"Kan ve katliama doymayan Ermeniler, yeni bir işgal denemesi yaparak sınırdaki sivil yerleşim birimlerine ateş açtı.” (Türkgün-28.09.2020)

“Azerbaycan'ın Ermenistan'ın saldırılarına anında cevap vermesi ve Karabă̆'1 kurtarmak için harekete geçmesi, bölgedeki dengeleri sarst1.” (Türkgün-30.09.2020)

“Bakan Çavuşoğlu, 'Temmuz ayında da çok güçlü bir uyarı gönderdik Ermenistan'a, aklını başına al. Tüm imkânlarımızla Azerbaycan ne istiyorsa yanındayız." (Türkgün$01.10 .2020)$

“TBMM'nin yeni yasama döneminde konuşan Cumhurbaşkanı Erdoğan, 'Azerbaycan'daki kardeşlerimin işgal altındaki topraklarını kurtarma mücadelesinde yanlarında olduğumuzu belirtmek isterim. Bu bölgede kalıcı barışın yolu, Ermenilerin işgal ettikleri her karış topraktan geri çekilmesindedir. Şimdi netice zamanı. Azerbaycanlı kardeşlerimiz de kendi göbeklerini kesmenin adımını attılar. Ermenistan’ı her şeyi bir kenara bırakıp, Türkiye'ye iftira atma çabaları da kurtarmayacak' diye konuştu.” (Türkgün$02.10 .2020)$

“Dağlık Karabağ sorununun çözülmesinde başlıca nedenin Ermenistan'ın barıştan yana olmaması olduğuna işaret eden Aliyev, Birleşmiş Milletler Güvenlik Konseyinin işgale kayıtsız şartsız son verilmesi gerektiği yönündeki 4 kararının, Erivan yönetimince hiçe sayıldığını hatırlattı. Aliyev, çözüm sürecini yürüten AGİT Minsk Grubunun 28 yıldır hiçbir sonuç elde edemediğini ifade etti.” (Türkgün-04.10.2020)

“'Bahçeli, Ermenistan'ın, Azerbaycan'ın ikinci büyük kenti Gence’ye saldırmasının, sivil ve masum soydaşlarımızı hedef almasının insanlık suçu ve uluslararası hukuku açıkça ihlal ve inkârı olduğunu söyledi." (Türkgün-05.10.2020) 
“Azerbaycan Savunma Bakanlığ1 Ermenistan ordusunun Fuzuli bölgesinde sivillerin yaşadığı Horadiz şehrine, Ağcabedi bölgesindeki köylere, Terter ve köylerine, Goranboy ve Göygöl bölgelerine saldırılar düzenlediğini açıkladı” (Türkgün-06.10.2020)

"Biz, iki devlet olsak da yeri gelirse aynı bayrak altında toplanır, Türklüğe kefen biçmeye çalış ne kadar zalim varsa hepsine karşı aynı sipere gireriz.” (Türkgün-07.10.2020)

“Ermeni kadın, Azerbaycan askerlerine, 'evinize hoş geldiniz' diye cevap verdi." (Türkgün-08.10.2020)

“Azerbaycan'ın Karabağ’’ işgalden kurtarmak için başlattığı harekât büyük bir başarı ile devam ederken, Ermenistan yine teröre, sivil katliamlarına ve cinayetlere yöneldi." (Türkgün-09.10.2020)

“Rus lider Putin'in çatışmalar için Azerbaycan ve Ermenistan’a yaptığı Moskova davetine iki ülke de olumlu cevap verdi” (Türkgün-10.10.2020)

Haberlerde ana olay Ermenistan'ın Dağlık Karabağ bölgesini işgali, yerleşim yerlerine saldırması ve Azerbaycan topraklarına saldırmasıdır. Gazeteler genelde ana olayı haber girişlerinde vermektedir. Üç gazete de ana olay olarak Ermenistan'ın sivillere olan saldırılarını ve Azerbaycan tarafindan "işgalden” kurtarılan bölgeleri haberleştirmektedir. Cumhuriyet gazetesi ise saldırıların ikinci gününden itibaren ateşkes görüşmelerinin gündeme gelmesiyle ateşkesi konu edinmektedir. Ancak Sabah gazetesi, ateşkes görüşmelerine değinmemekte, Azerbaycan'ın askeri başarılarında Türkiye yapımı SİHA'ların etkisinin büyük olduğu, Cumhurbaşkanı Erdoğan'ın ve Türkiye'nin Azerbaycan'ın yanında olduğu şeklinde vermektedir. Yine işgalden kurtarılan bir yerleşim yerinde ezan okunması, Azerbaycanlıların Türkiye ve Azerbaycan bayraklarıyla sevinç gösterileri yapmasıyla Azeri halkının Türkiye ve Erdoğan'a teşekkür etmeleri de haber girişlerinde ana olay olarak sunulmaktadır. Türkgün gazetesinde ana olay sunumları Azerbaycan tarafından ele alınmaktadır. Söylemlerde, Azerbaycan'ın hamleleri, politikaları vs. durumlar anlatılmakta ve baskın taraf olarak sunulmaktadır. Buna karşın Ermenistan'ın pasif ve Azerbaycan'ın baskısı altında olduğu hissettirilmektedir. Diğer yandan Türkgün gazetesi, Sabah gazetesiyle benzer şekilde ana olayları sunmakta fakat ek olarak Devlet Baçeli’nin sözlerine ve fotoğraflarına da yer vermektedir. Genel olarak ana olay sunumlarına bakıldığında Cumhuriyet gazetesi'nin ideolojik olarak daha nötr, Sabah gazetesinin SİHA ve Erdoğan vurgusu yaparak ideolojik 
olarak tarafgir konumlandığı görülmektedir. Bunun yanı sıra ezan, Türkiye ve Azerbaycan bayrakları gibi kültürel ve dini benzerlikleri sembolleştirip ana olay olarak sunarak iki ülke arasındaki ortaklıklara vurgu yaptığı görülmektedir. Türkgün gazetesinin Devlet Baçeli'nin sözlerini haber girişlerinde vermesiyle ideolojik olarak konumlandığı görülmektedir. Her üç gazetedeki haberlerde olayların sebebi olarak Ermenistan'ın Dağlık Karabăg işgali gösterilmekteyken olayın sonuç kısmında ise Azerbaycan'ın işgal altındaki topraklarını kurtarma operasyonu olarak verilmektedir.

b. Ardalan ve Bağlam Bilgisi

Haberlerde genel olarak ardalan ve bağlam bilgileri detaylı olarak verilmemiştir. Haberlere konu olan Ermenistan ve Azerbaycan arasındaki çatışmalarda Ermenistan saldırgan, sivillere zarar veren savaş suçu işleyen konumda konumlandırılmıştır. Tek yönlü olarak ele alınan haberlerde Azerbaycan işgal altıdaki topraklarını kurtarmaya çalışan ülke konumundadır. Ancak Cumhuriyet gazetesinin tek bir haberinde bugüne yansıyan çatışmaların sebepleri okuyuculara aktarılmıştır. Buna göre;

\begin{abstract}
"Bu sorunun bir geçmişi vardı. Kısa bir tarihsel özet verelim ve bu son çatışmanın sebepleri üzerinde duralım. Karabağ' daki sorunların kökleri çok eskiye dayanıyor. Karabağ'da ilk Türk-Ermeni çatışması 1905 yılında oldu. 1988 yılında Karabağ'daki Ermeniler, Sovyetler Birliği içinde ilk isyanı çıkararak Karabağ Ermenileri Ulusal Konseyi'ni kurdu ve Azerbaycan'dan ayrılarak Ermenistan'a bağlandığını ilan etti. 1991'de Sovyetler Birliği'ni dağılması sonucunda Ermeniler, Dağlık Karabağ'da özerklik ilan ettiler. 1992'de Ermenilerin giriştiği Hocalı Katliamı ile sorun vahşete dönüştü. Ermeniler, bu bölgedeki 7 kantonun tamamını ele geçirdi. 1992 Savaş1 öncesinde bölge nüfusunun yüzde 30'unu oluşturan 1 buçuk milyon Azerbaycan Türkü, yaşadıkları 7 bölge olan Laçin, Kelbecer, Ağdan, Fuzuli, Gubatlı, Cebrail ve Zengilan'dan kendi vatan topraklarından göç etmek zorunda kaldı." (Cumhuriyet01.10.2020)
\end{abstract}

Metniyle Ermenistan-Azerbaycan arasındaki çatışmaların ardalanı ve bağlamı okuyucuya aktarılmaktadır. Diğer haber metinlerinde Ermenistan'ın neden Dağlık Karabağ bölgesini işgal ettiği, olayın tarihsel ardalanı, siyasî ve sosyal bağlamına dair bilgiler bulunmamaktadir

c. Haber Kaynakları

Gazeteler haberlerini aktarırken kimliği bilinen ve kimliği bilinmeyen şeklinde iki türlü kaynağa atıfta bulunmaktadırlar. Bu kapsamda; 
Cumhuriyet gazetesi konuyla ilgili haberleri aktarırken;

“Azerbaycan Cumhurbaşkanlığg Uluslararası İlişkiler Müdürü” (Cumhuriyet28.09.2020)

“Bakü Eski Büyükelçisi Faruk Loğoğlu” (Cumhuriyet-29.09.2020)

“Moskova ve Ankara'nın açıklamaları” (Cumhuriyet-03.10.2020)

“Rusya Lideri Putin'in açıklamaları” (Cumhuriyet-08.10.2020)

“Azerbaycan'a göre yüzlerce, Ermenistan'a göre ise 31 adet Ermeni askerinin öldüğü” (Cumhuriyet-29.09.2020) ifadeleriyle Ermenistan da kaynak olarak kullanılmıştır. Bu nedenle Cumhuriyet Gazetesinin haber kaynaklarında Ermenistan'ın açıklamalarına da yer verdiği görülmektedir.

Şeklinde 4 haberde kimliği belli olan kişilerin açıklamaları kaynak olarak kullanılmıştır. Diğer 5 haberde ise kaynak bilgisi paylaşılmamıştır.

Sabah gazetesi konuyla ilgili haberleri aktarırken;

“Başkan Erdoğan:” (Sabah-28.09.2020)

“Başkan Erdoğan” ve “gazetenin muhabiri Uğur Yıldırım” (Sabah-29.09.2020)

“SABAH, Ermenistan saflarında savaşan PKK'lıların görüntülerine de ulaştı” (Sabah30.09.2020)

“Uğur Y1ldırım” (Sabah-01.10.2020, 02.10.2020, 03.10.2020, 04.10.2020, 05.10.2020, $06.10 .2020,07.10 .2020,08.10 .2020)$

8 haberde bölgeye gönderdiği kendi muhabiri Uğur Yıldırım'ın aktarımlarını kullanmıştır. Diğer 3 haberde ise Cumhurbaşkanı Erdoğan'ın ifadelerine yer verilirken Erdoğan'dan "Başkan Erdoğan” olarak bahsetmektedir. 1 haberde ise büyük puntolarla doğrudan kurumsal olarak kendisini kaynak göstermiştir. Sabah gazetesinin aktarımlarında Cumhurbaşkanı Erdoğan’dan "Başkan Erdoğan” olarak bahsetmesi aynı zamanda ideolojik tutumunun da bir örneğini oluşturmaktadır.

Türkgün gazetesi konuyla ilgili haberleri aktarırken sadece 09.10.2020 tarihli haberinde muhabiri Kadir Yıldız'ın görüşlerini kullanmıştır. Bunun dışındaki haberlerde ise herhangi bir uzman, muhabir veya kaynak gösterilmemiş, gazetenin genel görüşü olarak aktarılmıştır. 


\subsection{Mikro Yapı İncelemesi}

- Sentaktik Çözümleme

Sentaktik çözümlemede cümlelerin uzunluğu, kısalığı, aktif veya pasif oluşu ve öznelerin etken ve edilgen olarak konumlandırılması haberin aktarımında ideolojik yanlılığın olup olmadığı konusunda ipuçları vermektedir. Bu kapsamda;

Cumhuriyet gazetesinde Ermenistan'ın işgalci olduğu, Azerbaycan'ın ise işgal edilen topraklarını kurtarmak için savaştığı ifade edilmektedir. Haberlerin genel kurgusunda Ermenistan işgalci olduğu için etken, Azerbaycan ise işgal edilen olduğu için edilgen olarak konumlandırılmıştır. Ancak;

“Azerbaycan-Ermenistan çatışmasını değerlendiren Uluç Özülker, gerilimi TürkiyeRusya diyaloğunun çözeceğini söyledi” (Cumrhuiyet-30.09.2020) haberinde sorunun çözümünde Ermenistan ve Azerbaycan'ın değil Türkiye ve Rusya'nın etkili olacağı ifade edilmiştir. Söz konusu ifadelerle Türkiye-Rusya diyaloğunun etken Ermenistan-Azerbaycan'ın ise edilgen olduğunu ifade etmek mümkündür.

Haberlerde kullanılan cümleler kısa ve basit yapıda olup herhangi bir kelime oyunu yapılmamıştır. Bunun yanı sıra Ermenistan'ın herhangi bir açıklamasına yer verilmemiştir.

Sabah gazetesinde de Cumhuriyet gazetesiyle benzer şekilde Ermenistan'ın işgalci olduğu, Azerbaycan'ın ise işgal edilen topraklarını kurtarmak için operasyonlar düzenlediği ifade edilmektedir. Haberlerde Ermenistan işgalci olduğu için etken, Azerbaycan ise işgal edilen olduğu için edilgen olarak konumlandırılmıştır. Ancak Cumhuriyet gazetesinden farklı olarak Türkiye Cumhurbaşkanı Erdoğan'dan;

“Başkan Erdoğan:” (Sabah-28.09.2020; 29.09.2020)

“Başkan” olarak bahsedilmektedir. Dolayısıyla Türkiye Cumhuriyeti'nin hükümet şekli olan Cumhurbaşkanlığı Hükümet sistemi, makamın "cumhurbaşkanlığı" ve resmiyette “cumhurbaşkanı" olarak tanımlanmasına rağmen Cumhurbaşkanı Erdoğan'dan "başkan” olarak bahsederek, kelime oyunu yapmaktadır. Söz konusu kelime oyunuyla ideolojik olarak kendisini konumlandırmaktadır. Bunun yanı sıra Cumhurbaşkanı Erdoğan'ın açıklamalarında Erdoğan etken özne olarak konumlandırılmaktadır. Haberlerde kullanılan cümleler kısa ve basit yapidadir. 
Türkgün gazetesi Sabah ve Cumhuriyet gazeteleri gibi Ermenistan’1 işgalci olarak konumlandırırken, Azerbaycan'ın işgal edilen topraklarını kurtarmak için savaştığını ifade etmektedir. Türkgün gazetesi Sabah ve Cumhuriyet gazetelerinden farklı olarak MHP Genel Başkanı Devlet Bahçeli'nin ifadelerine de yer vererek ideolojik olarak kendisini MHP yanlısı olarak konumlandırdığı görülmektedir. Haberlerde kullanılan cümleler kısa ve basit yapıdadır.

- Sözcük Seçimleri

Haberlerde üç gazete de Ermenistan'ın saldırılarını tanımlarken Ermenistan'dan “işgalci” olarak bahsetmektedirler. Dolayısıyla üç gazetenin, Ermenistan’ı Türkiye'nin siyasi söylemlerinde ifade edilen şekilde "işgalci” olarak tanımlayarak, haksız ve suçlu konumuna yerleştirdiği belirtilebilir. Bu konuda üç gazete de ideolojik olarak benzer tavır göstermektedir.

\section{Cumhuriyet Gazetesi}

“Tuzağa düşülmemeli” (Cumhuriyet-29.09.2020) ifadesiyle Türkiye çatışmalar konusunda dikkatli olması gerektiği yönünde uyarılmaktadır.

"Hocalı Katliamı" (Cumhuriyet-01.10.2020) ifadesindeki katliam sözcügüyle Ermenistan'ın savaş suçu işlediği vurgulanmaktadır.

Ankara'nın ateşkes kararını “doğrulamadı̆̆ı” (Cumhuriyet-03.10.2020) ifadeleriyle Moskova'nın “yalan söylediği”” ima edilmektedir.

Cumhuriyet gazetesinin sözcük seçimlerinde daha itidalli olduğunu ifade etmek mümkündür. Ayrıca Hocalı hadisesini tanımlarken "katliam” sözcüğünü tercih etmesi ideolojik olarak konumlandığını göstermektedir.

\section{$\underline{\text { Sabah Gazetesi }}$}

“Örgüt, Azerbaycan'a karşı Ermeni dostlarının safında savaşmak için” (Sabah30.09.2020)

İfadesiyle PKK terör örgütüyle Ermenistan'1 “dostlarının” ifadesiyle birlikte anarak ve pekiştirerek Ermenistan’1 terörist olarak tanımlamaktadır.

“Aliyev: Erdoğan’a teşekkür ederim” (Sabah-01.10.2020) ifadeleriyle Azerbaycan Cumhurbaşkanının Erdoğan'a minnet duyduğunu ima etmektedir. 
“Haydut Devlet Karabağ'1 Terk Et”'(Sabah-02.10.2020) ifadeleriyle Ermenistan'ın haydut yani kural tanımayan devlet olarak tanımlamaktadır. Aynı tarihte yer alan “ikiyüzlülüktür” ifadesiyle diğer ülkelerin Ermenistan-Azerbaycan savaşında insan hak ve hürriyetleri çerçevesinde sessiz kaldıklarını vurgulamaktadır.

“Darmadağın ediyor” ve "büyük bozgun” (Sabah-03.10.2020) sözcük seçimleriyle abartı sanatı kullanılarak Ermenistan'ın ağır yenilgi aldığı çerçevelenmektedir.

"Ateş etmeyin teslim oluyoruz" "peş peşe teslim bayrağını çekiyor" (Sabah-04.10.2020) ifadeleriyle Ermenistan'ın yenilgi aldığı çerçevelenmektedir.

“Adım Adım Zafere” ve "sevinç gösterileri” (Sabah-05.10.2020) sözcük seçimleriyle Azerbaycan'ın galibiyetinde mübalağa sanatının kullanıldığı görülmektedir.

“27 y1l sonra ezan sesi” (Sabah-06.10.2020) sözcük seçimleriyle kültürel ve dini olarak Türkiye halkıyla benzerlik kurulmuş ve Türkiye halkının da dini ve kültürel duygularına gönderimde bulunulmuştur.

Azeri Türkçesi olan “aşk olsun” (Sabah-08.10.2020) ifadesinin Türkiye Türkçesinde "yaşasın” ifadesine karşılık geldiği belirtilmektedir. Böylece Türkiye ve Erdoğan'ın yardımlarına Azerbaycanlıların minnettarlık duydukları vurgulanmaktadır.

Haber başlığında kullanılan "tabana kuvvet kaçıyorlar” (Sabah-09.10.2020) ifadesi Türkçede bir deyim olarak kullanılmaktadır. Çok hızlı koşarak kaçıp gitmek ve panik halinde kaçmak anlamlarına gelmektedir.

Sabah gazetesinin sözcük seçimlerinde mübalağa sanatını kullandığını ifade etmek mümkündür. Bunun yanı sıra deyimlerden de faydalanarak aktardığı haberleri desteklediği görülmektedir. Türkiye'nin desteğinin önemine de vurgu yapılan haberlerde ideolojik olarak Türkiye ve Azerbaycan'ın desteklendiğini ifade etmek mümkündür

\section{Türkgün Gazetesi}

“Azgın Ermeni” (Türkgün-28.09.2020) ifadesiyle Ermenistan kontrol edilemeyen ve müdahale edilmesi gereken bir devlet olarak konumlandırılmaktadır. Böylece Azerbaycan'ın operasyonları dolaylı olarak haklılaştırılmaktadır.

“Hesap vakti” (Türkgün-29.09.2020) ifadesiyle Ermenistan'ın suçlu olduğu ve cezasını çekeceği ima edilmektedir. 
“Azerbaycan ne isterse yaparız" (Türkgün-01.10.2020) ifadesiyle koşulsuz olarak Azerbaycan'ın yanında konumlanıldığg vurgulanmaktadır.

“Karabağ Azat Olmadan Bu Ateş Kesilmez” (Türkgün-03.10.2020) ifadesiyle savaşın son bulması için Azeri Türkçesi de kullanılarak Karabağ’ın işgalden kurtarılması şartı vurgulanmaktadır.

“Ermenistan Terör Devleti” (Türkgün-06.10.2020) ifadesiyle Ermenistan ve terör bir arada kullanılarak Ermenistan olumsuzlanmaktadır.

“Ermenistan-PKK Terör Ortakları” (Türkgün-09.10.2020) cümlesiyle Türk halkı için Ermenistan ve PKK'nın terörist olduğu yönünde izlenim uyandırılmak istenmektedir.

Türkgün gazetesinin sözcük seçimlerinde Ermenistan'a karşı saldırgan ifadeler kullandığını ifade etmek mümkündür. Yine sözcük seçimlerinde Azeri Türkçesine yer verilmesi Azerbaycan'ın desteklendiği şeklinde okunabilir. Türkiye'nin desteğinin önemine de vurgu yapılan haberlerde ideolojik olarak Türkiye ve Azerbaycan'ın desteklendiğini ifade etmek mümkündür.

- Retorik

Haber metninin inandırıcılığını artırmak için retorik unsurlar önem taşımaktadır. Bu bağlamda Cumhuriyet gazetesinin;

“Eski Bakü Büyükelçisi Faruk Loğoğlu” (Cumhuriyet-29.09.2020)

“Eski Büyükelçi Uluç Özülker” (Cumhuriyet-30.09.2020)

"Bu sorunun bir geçmişi vardı. Kısa bir tarihsel özet verelim ve bu son çatışmanın sebepleri üzerinde duralım. Karabağ' daki sorunların kökleri çok eskiye dayanıyor. Karabağ' da ilk Türk-Ermeni çatışması 1905 yılında oldu. 1988 yılında Karabağ' daki Ermeniler, Sovyetler Birliği içinde ilk isyanı çıkararak Karabağ Ermenileri Ulusal Konseyi'ni kurdu ve Azerbaycan'dan ayrılarak Ermenistan'a bağlandığını ilan etti. 1991'de Sovyetler Birliği'ni dağılması sonucunda Ermeniler, Dağlık Karabağ'da özerklik ilan ettiler. 1992'de Ermenilerin giriştiği Hocalı Katliamı ile sorun vahşete dönüştü. Ermeniler, bu bölgedeki 7 kantonun tamamını ele geçirdi. 1992 Savaş1 öncesinde bölge nüfusunun yüzde 30'unu oluşturan 1 buçuk milyon Azerbaycan Türkü, yaşadıkları 7 bölge olan Laçin, Kelbecer, Ağdan, Fuzuli, Gubatlı, Cebrail ve Zengilan'dan kendi vatan topraklarından göç etmek zorunda kaldı." (Cumhuriyet01.10.2020)

Ağırlıklı olarak konu hakkındaki uzmanların görüşlerine yer verdiği görülmektedir.

$\mathrm{Bu}$ görüşleri doğrudan alıntılar şeklinde aktarmaktadır. Ayrıca tarihsel ardalanı aktarırken tarih bilgilerine ve yüzdelik dilimlerle sayısal veriler paylaştığı görülmektedir. 
Sivillerin hedef alındığı 29.09.2020 ve 05.10.2020 tarihli haberlerindeyse sahadan fotoğraflar paylaşılmıştır. Son olarak da ateşkes görüşmelerini kanıtlamak için 10.10.2020 tarihli haberinde Rusya'daki görüşmenin fotoğrafi kullanılmıştır.

Sabah gazetesinin ise her haberinde birden fazla fotoğraf kullandığı görülmüştür. Ayrica;

"130 tank ve zırhlı aracı, 200 top ve füze sistemini, 50 tanksavar silahını imha etti. Ermenistan'a ait iki SU-25 savaş uçağ1 da dağa çarparak düştü” (Sabah-01.10.2020)

“Karabağ’ın elektriğinin yüzde 70'ini sağlayan baraj da kontrol altına alındı. ...Çatışmalarda 4 Ermeni tankı vuruldu, 3 tank ile çok sayıda mühimmat ele geçirildi” (Sabah05.10.2020)

“Karabağ’da 27 yıl sonra ezan sesi” (Sabah-06.10.2020)

“...11 günde 27 yerleşim yerini işgalden kurtardı” (Sabah-08.10.2020)

İfadeleriyle sayısal veriler, yüzdelik ve tarihsel veriler retorik ispat için kullanılmıştır.

Türkgün gazetesinde retorik için herhangi bir uzman görüşü veya istatistiki veri kullanılmamaktadır. Ancak bunun yerine özellikle sözcük seçimleri ve haber başlıklarında kullandığ ifadeleriyle daha çok pathos (duygusal) yönü ağır basan retorik kullanmıştır. Böylece Azerbaycan ve Türkiye arasındaki dini ve milli yakınlık sebebiyle var olan duygusal bağı yine duygular üzerinden ifade etmeye çalışmaktadır.

\section{SONUÇ}

Çalışmada ilgili haberlere yapılan eleştirel söylem analizi sonucunda ideolojinin haber metinlerine belirgin şekilde yansıdığı tespit edilmiştir. Gazeteler konuyu okuyucularına aktarırken ideolojik yapılarına göre söylemlerini düzenledikleri ve bu doğrultuda okuyucularını ikna etmeye çalıştıkları görülmüştür. Bu kapsamda başlıklar, haber girişleri ve fotoğraflardan oluşan makro yapı aracılığıyla haber metinlerini belli bir çerçeve içerisinde yapmışlardır. Yorum içeren haberlerde Cumhuriyet gazetesinin konunun uzmanlarına başvurduğu görülmüştür. Sabah gazetesinin ise bölgede bulunan muhabirinin aktarımlarına ve Cumhurbaşkanı Erdoğan'ın söz konusu çatışmalarla ilgili ifadelerini kaynak olarak kullandığı, Erdoğan'ın açıklamalarını "Başkan Erdoğan” olarak yansıtarak ideolojik olarak konumlandığı görülmüştür. Sabah gazetesinde dikkat çeken diğer bir nokta ise Azerbaycan halkıyla Türkiye 
halkının din, dil ve kültür gibi ortak noktalarına vurgu yapılarak haberlerin şematik olarak sunuluşu ve sözcük seçimlerinde de bu vurgunun ön plana çıkartılmasıdır. Türkgün gazetesinde de din, dil ve kültür yakınlığından dolayı söylem Azerbaycan'ın açıkça desteklenmesi şeklinde oluşmuştur. Bu söylemin oluşmasında Türkgün gazetesinin MHP ile olan ideolojik bağlılığ etkili olmaktadır. MHP’nin siyasi anlayışının milliyetçi ve muhafazakar olması, ideolojik yakınlık sebebiyle bu anlayışın haber metinlerine yansımasını sağlamıştır. Cumhuriyet gazetesi ise daha çok nesnel bilgiler aktarmış, kültür, din ve dil gibi ortak faktörlerin etkisinde kalmadan ideolojik olarak daha tarafsız pozisyonda konumlandığı görülmüştür. Ayrıca, haber aktarımında verilen kayıplar hakkında Ermenistan'ın da iddialarını haber başlığına taşıyarak karşı tarafa da söz verdiğini ifade etmek mümkündür.

Haberlerde bağlam bilgisi ve ardalan bilgisi yok denecek kadar azdır. Cumhuriyet gazetesinin tek bir haberi dışında diğer haberler bağlam ve ardalan bilgilerinin azlığından dolayı tek tipleştirilmiştir. Haberlerde olay anına değinilmekte ve Ermenistan'ın işgali ve saldırıları sonucu çatışmaların başladığı ön plana çıkartılmaktadır. Haberlerde bu şekilde ardalan ve bağlam bilgilerinin atlanarak verilmesinde ideoloji, kültür ve dini sebepler yattığı ifade edilebilir. Bütün haberlerde Azerbaycan'ın haklı olduğu vurgulanmasında yine bu sebeplerin olduğu söylenebilir. Cumhuriyte gazetesinin milli yakınlık, Sabah gazetesinin ideolojik, dini ve kültürel yakınlık, Türkgün gazetesinin de yine ideolojik, dini ve kültürel yakınlık sebebiyle ardalan ve bağlam bilgisini kurmadan Azerbaycan’ı desteklenmesi açıklanabilir. Bunun yanı sıra üç gazetenin de Ermenistan'ın saldırılarında zarar gören sivilleri haberleştirdiği ve bu konuda hassasiyet gösterdiği görülmüştür. Ancak Azerbaycan'ın saldırılarında herhangi bir sivilin zarar görüp görmediğine dair paylaşım bulunmamaktadır. Dolayısıyla bu konuda ideolojik olarak taraf olunduğu, olayın bir yönünün öne çıkarılarak okuyuculara aktarıldığı ifade edilebilir. Haberlerde retorik unsur olarak okuyuculara olayları kanıtlamak için ağırlıklı olarak fotoğraflar kullanılmıştır. Ancak, Sabah ve Türkgün gazetelerinin Cumhuriyet gazetesine göre daha fazla görseli bir arada kullandığı, Cumhuriyet gazetesinin ise daha çok uzman görüşlerine yer verdiği sonucuna ulaşılmıştır. Burada da yine Sabah ve Türkgün gazetelerinin duygusal retoriğe önem vermesinin etkisi görülmektedir.

Üç gazetenin haber metinlerine yansıyan ideoloji, din ve kültür sebebiyle söylemin farklılaşmasının yanında milli ve etnik sebeplerle ortak yaklaşım sergilediği de tespit edilmiştir. Bu kapsamda, üç gazetenin de Ermenistan’1 “işgalci” olarak gördüğünü ifade etmek 
mümkündür. Gazetelerin Ermenistan'ı işgalci olarak tanımlamaları gerek Türkiye Cumhuriyeti'nin gerekse uluslararası kuruluşların ve diğer ülkelerin Karabağ bölgesinde Ermenistan'ı işgalci olarak tanımlamalarından kaynaklıdır. Sabah gazetesinin ateşkes görüşmeleriyle ilgili herhangi bir yorumda bulunmadı̆̆ı, Ermenistan ve Azerbaycan arasındaki çatışmalarda önemli rol üstlenen Rusya'ya değinmediği de görülmüsştür. Sabah gazetesinin haberler söylemini oluştururken daha çok Azerbaycan'ın edindiği başarıları ön plana çıkarttığı görülmüştür. Türkgün gazetesi Azerbaycan'ın savaşı devam ettirerek Karabağ bölgesindeki toprakların tamamını alması gerektiğini vurgulmıştır. Hatta ateşkesin ilan edildiği günün ertesinde operasyonların durmayacağı ifade edilmiştir. Cumhuriyet gazetesi ise çatışmaların ikinci gününden itibaren ateşkesi gündemine aldığı, Rusya'nın hamlelerinin önemli olduğu ve iki ülke arasındaki çatışmalarda Rusya'nın da hesaba katılarak hareket edilmesi gerektiği "tuzağa düşülmemeli" ifadesiyle vermiştir. Bu nedenle Sabah ve Türkgün gazetelerinin Azerbaycan'ın Karabağ bölgesinin tamamını işgalden kurtarılması yönünde taraf olduğu, Cumhuriyet gazetesinin ise ateşkesin de konuşulması yönünde yanlılı̆̆ı olduğu sonucuna ulaşılmıştır.

Sözcük seçimlerinde Sabah gazetesinin deyimlere yer verdiği ve haberleri aktarırken anlatısal kapanmaya başvurarak okuyucunun zihninde haber metinlerini gazetenin aktarmak istediği biçimde tamamlaması sağlanmaktadır. Söz konusu metotla okuyucu için diğer ihtimaller dışlanmaktadır. Türkgün gazetesindeki sözcük seçimlerinde ise daha çok mücadele ve hak arayışı vurgulanmaktadır. Okuyucularını Azerbaycan'ın haklı davasından geri dönmemesi gerektiği konusunda duygusal olarak harekete geçirmeye çalışmaktadır. Cumhuriyet gazetesinin ise açık metinler kullandı̆̆ı, böylece haber metninin yorumunu okuyucunun zihnine bıraktığı görülmüştür. Ancak üç gazete Karabağ hadisesini Ermenistan'ın “işgali” olarak tanımlamakta ve çatışmalarda zarar gören siviller konusunda da sadece Ermenistan'ın saldırılarının sonucu olarak paylaşımda bulunmaktadır. Böylece hâkim söylemi yeniden ürettikleri sonucuna ulaşılmaktadır. Zira Althusser'in (2000, s. 34-35) de belirttiği gibi basın, devletin bir ideolojik aygıtıdır ve baskı aygıtlarının tahakkümü altındadır. Çalışmanın sonucunda Sabah gazetesinin Ermenistan-Azerbaycan çatışmasıyla ilgili nesnel haber yapmadığı ve ideolojik yanlılığının olduğu, Türkgün gazetesinin de ideolojik, dini ve kültürel etkilerden dolayı çatışmayı tek taraflı aktardığı, Cumhuriyet gazetesinin ise zaman zaman 
nesnel olmaya çalıştığı ancak genel olarak milli yakınlık sebebiyle egemen söylemi devam ettirdiği sonucuna ulaşılmıştır.

\section{EXTENDED ABSTRACT}

There are two approaches to reporting an event, mainstream liberal and critical. According to mainstream liberal approach it is mentioned that there are some professional routines such as news value, objectivity and impartiality in reporting the events. However, the critical approach claims that these routines serve to construct the ideology hidden in the news and to hide the main purpose. Moreover, in the critical approach, it is claimed that these effects are reflected in the news as ideology, meaning, language and discourse. Due to these effects, the prevailing opinion is that the news does not reflect the truth, that is, the actual event and the event reported in the news text are different. The discourses contained in the news text are considered ideological discourses created by news professionals for the continuation of hegemony and for society to normalize this hegemony. Thus, the ideologies of the ruling or power holders are tried to be attributed to society through news texts. Van Dijk states that when the discourses are analyzed with a critical point of view, the socio-political position, perspective, aims and principles of the news text can be determined. From these identified features of the news text, it will be possible to learn about the relationship between power and ruler, the social and cultural situation, and what inequalities are trying to achieve.

Critical discourse analysis is based on the fact that the ruling class controls information through the media, and this control has an effect on the perception of information by the society. It also reveals the ideological reflection in the expressions that are naturally included in the texts or placed consciously. Considering the parameters on which discourse is affected, ideology comes to the fore. Since ideology cannot be strictly restricted within a fixed area, it can affect every aspect of daily life by being formed everywhere regardless of time and place. Van Dijk states that ideology emerges at the level of discourse in our daily life and speech. In addition, it emphasizes ideology as shared values in the community and cultural environment.

The study will focus on the bias of newspaper news in the light of this information. The way in which the clashes between Armenia and Azerbaijan were reflected in the progovernment Sabah newspaper, the opposition Cumhuriyet newspaper and nationalist Turkgun 
newspaper in terms of bias, ideological reflection and power relations in the news was analyzed with the critical discourse analysis method of van Dijk. The study covers the reflections on the first pages of the relevant newspapers in the printed versions of the news between 28.10.2020, the date of the clashes started, and the date of 10.10.2020, when the Russian Federation intervened and the ceasefire was declared. Within the scope of the study, Cumhuriyet newspaper published 9 articles, Sabah newspaper 11 articles and Turkgun newspaper 13 articles on the relevant dates. The dates when the conflicts resumed and the ceasefire agreement was signed constitute the limitation of the study. Another limitation is that the news in the relevant newspapers is limited to first page news. In the preference of first pages in news reviews, the main reason is that the main message and ideological bias are more pronounced.

The determined news were analyzed in two main sections as macro and micro structure analysis based on critical discourse analysis and each section was formulated from its own subsections. The macro structure is divided into two subheadings as thematic and schematic analysis. In the thematic analysis, headlines, spot or news entries were analyzed. In the schematic analysis, context and background information, the presentation and results of the main event, and the sources where the news is fed were examined. In microstructural analysis, the syntactic length of sentences and the positioning of subjects as active or passive have been the reflection of ideology in the text. Word choices enabled the ideology to emerge more prominently in microstructural analysis. Therefore, the words chosen clearly reveal the ideology of the journalist or newspaper. In the rhetoric part, it was analyzed whether the sources such as statistical data and photographs were used to prove the statements or claims in the news text, and it was seen that many rhetorical techniques were used to persuade the reader.

As a result of the critical discourse analysis, it was determined that the newspapers presented their news on the conflicts between Azerbaijan and Armenia in a certain way. It made the news texts within a certain frame by means of the macro structure consisting of headlines, news entries and photographs. It was observed that Cumhuriyet newspaper applied to the experts of the subject in the news with comments. It was observed that Sabah newspaper used the statements of the reporter in the region and the statements of President Erdogan about the clashes in the region, and it was ideologically positioned by reflecting Erdogan's statements as "President Erdogan". Unlike other two newspapers Turkgun newspaper used Nationalist Party's Chairman Devlet Bahçeli's statements and photographs. All three newspapers consider 
Armenia as an "occupier". In particular, Sabah and Turkgun newspapers emphasized the partnerships of religion, language and culture between Azerbaijan and Turkey, and conservative discourses were used. Cumhuriyet newspaper, did not address the partnership of religion, language and culture. As a general assessment, it was found that Cumhuriyet newspaper preferred an ideological discourse that stayed away from conservatism, while Sabah newspaper adopted a more conservative discourse in its texts, reflecting its ideological affinity with power in its texts. Turkgun newspaper preferred more nationalist discourse and reflectin its ideological affinity.

\section{KAYNAKÇA}

Althusser, L. (2000). İdeoloji ve devletin ideolojik aygıtları. (Y. Alp, \& M. Özışı, Çev.) İstanbul: İletişim Yayınları.

Arslanl1, A. (2015). Karabă̆ sorunu ve Türkiye Ermenistan ilişkileri. Ankara: Berikan Yayınevi.

Aslanlı, A., \& Hesenov, İ. (2005). Haydar Aliyev dönemi Azerbaycan'ın dış politikası (19932001). Ankara: Platin Yayınları.

Aydın, M. (2010). Ermenistan'la ilişkiler. B. Oran içinde, Türk dış politikası cilt 2: 1980-2001 (s. 406-416). İstanbul: İletişim Yayınları.

Büyükkantarcıoğlu, N. (2012). Söylem incelemelerinde eleştirel dilbilimsel boyut: Eleştirel söylem çözümlemesi ve ötesi. Ö. Özer içinde, Haberi eleştirmek (s. 161-198). Konya: Literatürk.

Demir, A. F. (2005). SSCB sonrası dönemde Türkiye-Ermenistan ilişkileri. Uluslararası İlişkiler, 5(2), 109-135.

Dikkaya, M. (2009). Orta Asya ve Kafkasya dönüşüm süreci ve uluslararası ekonomi politik. İstanbul: Beta Yayınevi.

Doğru Arsa, E. (2004). Medya-güç ideoloji ekseninde Merve Kavakçı haberlerinin iki farklı sunumu. Ç. Dursun içinde, Haber hakikat ve iktidar ilişkisi (s. 151-183). Ankara: Elips Kitap. 
Dursun, Ç. (2001). TV haberlerinde ideoloji. Ankara: İmge Kitabevi.

Dursun, Ç. (2004). Haberde "gerçekliğin inşa edilmesi ne demektir?". Ç. Dursun içinde, Haber hakikat ve iktidar ilişkisi (s. 37-67). Ankara: Elips Kitap.

Eagleton, T. (2015). İdeoloji. (M. Özcan, Çev.) İstanbul: Ayrıntı Yayınları.

Ekşi, M. (2009). Türkiye-Azerbaycan ilişkileri: Söylemden reelpolitiğe. Avrasya Etüdleri, 36(2), 95-112.

Eren, S. (2012, 10 18). Kardeş ülke 21 yaşında. Sabah Gazetesi.Erişim adresi: https://www.sabah.com.tr

Fairclough, N. (1992). Discourse and social change. Cambridge: Polity Press.

Gerbner, G. (2014). Medyaya karşı. (G. Ayas, V. Batmaz, \& İ. Kovacı, Çev.) İstanbul: Ayrıntı Yayınları.

Gökçe, M. (2012). Siyah altın peşinde: Hazar'da bin yıl. Ankara: Berikan Yayınları.

Gökçe, M. (2014). İki kardeş devletin ortak sorunu: Karabă̆ ve Ermeni meselesi. Yeni Türkiye, Eylül-Aralık(63), 2687-2698.

Görgülü, A. (2008). Türkiye-Ermenistan ilişkileri: Bir kısır döngü. Dış politika analiz serisi. Erişim adresi: https://www.tesev.org.tr/wpcontent/uploads/rapor_Turkiye_Ermenistan_Iliskileri_Bir_Kisir_Dongu.pdf

Güllüoğlu, Ö. (2012). Söylenmeyenin analizi: Bellona markasına yönelik tüketici algısı üzerine bir söylem analizi. Ö. Güllüoğlu içinde, İletişim bilimlerinde araştırma yöntemleri yazılı metin çözümleme (s. 225-274). Ankara: Ütopya Yayınevi.

Hall, S. (1994). İdeolojinin yeniden keşfi: Medya çalışmalarında baskı altında tutulanın geri dönüşü. M. Küçük içinde, Medya, iktidar, ideoloji (M. Küçük, Çev., s. 57-105). Ankara: Ark Yayınevi.

İnal, A. (1995). Yazılı basın haberlerinde 'yapısal' yanlılık sorunu. Toplum ve Bilim, Güz(67), 111-135.

İnal, A. (1996). Haberi okumak. İstanbul: Temuçin Yayınları. 
Kurat, A. N. (1999). Rusya tarihi. Ankara: Türk Tarih Kurumu.

Lippmann, W. (1922). Public opinion. New York: Harcourt, Brace and Company.

Özer, Ö. (2000). Haberde egemen söylemin yeniden üretimi: Türk basınında Türkiye'deki İranlı muhaliflerle ilgili haberler. Kültür ve İletişim, 3(2), 75-97.

Özer, Ö. (2011). Haber söylem ideoloji \& eleştirel haber çözümlemeleri. Konya: Literatürk Yay.

Özer, Ö. (2015). Teun Adrian Van Dijk örneğinde eleştirel söylem çözümlemesi. B. Yıldırım içinde, Illetişim araştırmalarında yöntemler (s. 197-286). Konya: Literatürk.

Sancar, S. (2014). İdeolojinin serüveni: Yanlış bilinç ve hegemonyadan söyleme (3 b.). Ankara: İmge Kitabevi.

Sözen, E. (1997). Medyatik hafiza. İstanbul: Timaş Yayınları.

Ş1haliyev, E. (2004). Azerbaycan-Ermenistan ilişkilerinde Rusya ve İran faktörü (1828-2000) (yayımlanmamış doktora tezi). Ankara: T.C. Ankara Üniversitesi Sosyal Bilimler Enstitüsü Tarih (Genel Türk Tarihi) Anabilim Dalı.

Taşkıran, C. (1997). Karabağ'da son durum. Yeni Türkiye, Temmuz-Ağustos(16), 1192-1198.

Van Dijk, T. (1988). News analysis. New Jersey: Lawrance Erlbaum Associates.

Van Dijk, T. (1993). Principles of critical discourse analysis. Discourse and Society, 4(2), 249283. doi:https://doi.org/10.1177/0957926593004002006

Yağl1, S. (2007). Haber ve ideoloji ilişkisi: Haber metinlerinde gerçekliğin sunumu. Ege Üniversitesi İletişim Fakültesi Yeni Düşünceler Hakemli E-Dergisi(2), 337-353.

Yardım, G., \& Doğruel, H. (2019). Eleştirel söylem çözümlemesi bağlamında haber metinlerinin incelenmesi: Pippa Bacca cinayeti örneği. Erciyes İletişim Dergisi, 6(1), 137-148. 